\title{
OS PERITOS DOS PROCEDIMENTOS ESPECIAIS DO SISTEMA DE DIREITOS HUMANOS DAS NAÇÕES UNIDAS: seu status jurídico e outras questões pertinentes
}

\author{
Silvia Menicucci de Oliveira
}

\begin{abstract}
Resumo:
Os procedimentos especiais do sistema de direitos humanos das Nações l'nidas têm como ubjetivo averiguar as situações e aprofundar no exame de temas de direitos humanos de interesse da comunidade internacional, além de garantir a transparência na questão da realização dos direitos humanos e das liberdades fundamentais c na relação entie os governos dos Estados-membros e órgãos internacionais, tais como a Comissão de Direitos Humanos, que lidam com a supervisão do cumprimento das normas internacionais de direitos humanos. Esses procedimentos passaram a ser utilizados com maior freqüência em face de situações nacionais ou temas especificos relacionados aos direitos humanos, tendo resultados importantes para a garantia destes direitos. Em geral. os mandatos destes procedimentos são atribuidos a peritos. que apresentam status jurídico especial, nos termos da normativa internacional e dos pareceres consultivos da Corte Internacional de Justiça.
\end{abstract}

Palavras-chave: Sistema de direitos humanos das Nações Unidas. Procedimentos especiais. Status juridico. Mandatos dos peritos.

\begin{abstract}
:
The special procedures of the United Nations system of human rights werc created to check out some situations and go deeper into the exam of human rights issues, which may be of special interest to the international community. Besides that, they safeguard the transparency on the question of realization of human rights and fundamental freedoms and on the relation between the governments of Member States and the international bodies, as the Human Rights Commission, which deal with the monitoring of the compliance with the international norms of human rights. These procedures have been used more frequently in national situations or specific themes related to human rights, and have shown important results to the safeguard of the rights. In general, the mandates of these procedures are attributed to experts, which have special legal status. according to the international normative and the advisory opinions of the International Court of Justice.
\end{abstract}

Keywords: United Nations Human Rights System. Special Procidures. Legal status. Experts' mandatis.

Mestre e doutoranda em Direito Internacional pela Faculdade de Direito da Universidade de São Paulo. Bolsista da FAPESP. 


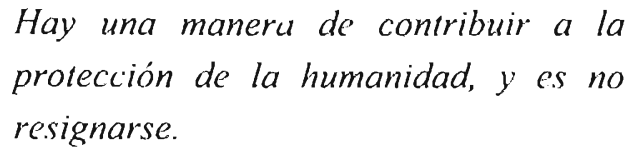

(Ernesto Sabato. La Resistencia, 2000)

\section{Introdução}

Nos anos 60 e 70, em razão dos abusos do regime de apartheid na África do Sul e do regime militar chileno, a Comissão de Direitos Humanos (CDH) das Nações Unidas agiu com inovação ao instituir um procedimento especial para averiguar a situação de não observância das normas internacionais e desrespeito aos dircitos humanos. Com o tempo, a iniciativa acerca de temas específicos somou-se aos outros precedentes, criando um novo espaço em âmbito internacional para a consideração de situações de graves e sistemáticas violações aos direitos humanos. $\mathrm{Na}$ linguagem das Nações Unidas. essa novidade ganhou a denominação de procedimentos especiais, que, em linhas gerais, compreendem um sistema destinado a averiguar as situações e aprofundar no exame de temas de direitos humanos de interesse da comunidade internacional. Um dos scus propósitos é garantir a transparência na questão da realização dos direitos humanos e das liberdades fundamentais e na relação entre os governos dos Fstados-membros com órgãos internacionais, tais como a $\mathrm{CDH}$, que lidam com a supervisão do cumprimento das normas intemacionais de direitos humanos.

Nos últimos anos, o Brasil adotou medidas para aprofundar a cooperação e o diálogo com os procedimentos especiais que envolvem mandatos temáticos da CDH. Em 19 de dezembro de 2001, o então presidente Fernando Henrique Cardoso formulou um convite aberto aos peritos relacionados a direitos humanos do sistema das Nações Unidas para visitas ao Brasil sempre que assim o desejarem. ' Como ressaltou o secretário

1 Deve-se entender que a decisão do governo federal de estender um convite aos procedimentos especiais de direitos lumanos, por mcio do poder executivo, feita em nome do Estado brasileiro como um todo, vincula os poderes nacionais. A competència constitucional reside nas disposições do art. 21 , I e do art. 84, VII, VIII. XIX, XX, XXII da Constituição Federal uma vez que manter relaçõus com outros Estados e organizações internacionais $\dot{e}$ um poder constitucionalmente conferido à União Federal, exercido por meio de seu executivo. Embora possa haver discussão a respeito da questão de diplomacia parlamentar ou do controle político do Executivo nas suas relaçōes internacionais, essa é uma discussão interna a respeito da divisão dos poderes e o Dircito Internacional nãu lida cum a separação dos poderes, mas com os Estados. $O$ Brasil como um Estado, ou seja, sujeito dotado de personalidade juridica internacional, é considerado de forma homogênea no âmbito internacional. Sobre essa discussão ver: SOARES. Guido Fernando Silva. Imunidade de jurisdição e foro por prerrogativa de função. Texto baseado nas notas taquigráficas de conferência proferida no Seminário Internacional O Tribunal Penal Internacional e a Constituição Brasileira. promovido pelo Centre de Estudos Judiciários do Consclho da Justiça Federal, em 30 de selembro de 1999, no auditório do Superior Tribunal de Justiça, em Brasilia-DF. 
de Estado dos Dircitos Humanos do respectivo governo, Paulo Sérgio Pinheiro, ${ }^{2}$ o Brasil tornou-se o primeiro país na América do Sul, e o décimo segundo no mundo, a estender esse tipo de convite aos relatores das Nações Unidas, tornando supérflua a costumeira autorização para entrada da missão no país. A iniciativa brasileira destacou-se entre os poucos países em desenvolvimento como uma demonstração de abertura no campo dos direitos humanos, ainda mais, ao se levar em conta o passivo na realização dos direitos humanos, verificado no âmbito nacional. Nesse contexto, entre 1993 e 2004. o Brasil recebeu a visita de relatores especiais para temas como a prostituição e a pornografia relacionadas a crianças, a violência contra a mulher, o racismo e a discriminação racial, os direitos humanos e os resíduos tóxicos, a tortura, o direito à alimentação, as execuções extrajudiciais, sumárias ou arbitrárias, o direito ao desenvolvimento, e a independência de juízes e advogados.

Em geral, após as visitas, são apresentados relatórios à $\mathrm{CDH}$ que assinalam os pontos positivos e aspectos preocupantes identificados durante a visita, e formulam recomendações para melhorar a situação geral dos direitos humanos no país, no contexto de um diálogo construtivo. Em inúmeras vezes, o governo brasileiro recebeu essas observações com naturalidade e procurou traduzir em medidas concretas a grande maioria das recomendações. ${ }^{3}$ Contudo. em 2003. a visita da então Relatora das Nações Unidas para Execuções Extrajudiciais, Sumárias e Arbitrárias, a paquistanesa Asma Jahangir, causou polêmica no âmbito nacional. Após efetuar alguns levantamentos e entrevistas acerca de graves e sistemáticas violações dos direitos humanos no Brasil, a relatora ponderou publicamente a necessidade de outras visitas ao país, notadamente para inspecionar o grau do envolvimento do sistema de justiça nessas violações, sendo que a visita do relator especial sohre independência de juízes e advogados realizada em 25 de outubro de 2004 é um resultado direto do relatório de Asma Jahangir. Surgiram alegações no seio do Supremo Tribunal Federal no sentido de que a atuação da relatora era uma intromissão indevida nos assuntos domésticos do país, uma ameaça à soberania do Brasil, e de que a conduta do executivo ameaçava a independência do judiciário ao permitir a investigação dos tribunais nacionais. Tais argumentos demonstram a persistência no nível

PINHEIRO. Paulo Sérgio: (iAMA, Marcos Pinta. Portas abertas às Nações Unidas. Jornal 'O Globo', 15 de abril de 2002.

Exemplos podem ser citados: (i) como resultado do diálogo estabelecido em 2000 com o Relator Especial para tortura, o governo federal lançou em 2001 uma campanha nacional contra a prática da tortura; (ii) a missão do Relator para racismo em 1995 ajudou a derrubar o mito da democracia racial no pais e abriu caminho para discussão e adoção em 2001 de programas de ação afirmativa em favor de afro-descendentes e outros grupos discriminados, no espirito dos compromissos assumidos na Conferência Mundial contra o Racismo em Durban, África do Sul. 
doméstico de traços de alienação em relação à normativa e aos mecanismos de direitos humanos $^{3}$ e uma profunda clesconsideração da importância da transparência do poder, qualquer que seja ele, em uma sociedade democrática. ${ }^{\varsigma}$ A atuação da relatora deve ser interpretada como um convite à cooperação internacional, na medida que seu mandato foi estabelecido pela Resolução n. 1.982/35, de 7 e maio de 1982, do Conselho Econômico e Social das Nações Unidas que ustabelece tarefas de investigação acerca de diversos aspectos relacionados às execuções, com o intuito de aprimorar os padrõus domésticos de respeito aos direitos humanos fundamentais e a nivelá-los às normas internacionais, mediante recomendações e diálogo com os governos. ${ }^{6}$

As reações infundadas acima comentadas, que demonstraram desconhecimento da natureza juridica desses relatores, bem como de seus métodos de trabalho e da interação de suas recomendações com a ordem interna. despertaram a atenção para a necessidade de esclarecimento de algumas questões a partir de uma análise do ponto de vista do Direito Internacional. Além dessa importância relativa em decorrência da experiência brasilcira na interface da política nacional de dircitos humanos com os procedimentos especiais do sistema das Nações Unidas, há uma importância geral na investigação dessa temática em razão de sua contribuição à transparência nos assuntos internacionais e à realização dos direitos humanos. Esse artigo tcm. portanto, como objetivo esclarecer as questões juridicas a respeito dos procedimentos especiais de direitos humanos das Nações Unidas. Nesse escopo, inicialmente procurou-se situar tais procedimentos no sistema onusiano de direitos humanos a partir da diferenciação entre os mecanismos convencionais e extra-convencionais. Essa abordagem institucional informa a investigação do status jurídico dos titulares de mandatos relacionados aos procedimentos

ARAGÃO, Eugênio Iosé Guilherme de. ONU e o judiciärio. Observatório da Imprensa, Matérias, 11/11/2003. Como lembra José Carlos Magalhães em referência ao sistema interamericano de direitos humanos, na época do regime militar, o Brasil foi denunciado à Comissão Interamericana por violaçõcs ao Pacto de São José da Costa Rica, e recusou-se em dois casos a permitir inspeçào local, para verificação das denúncias de tortura e homicidio, sob fundamento de que viulariam a soberania nacional. MAGALHÃES, José Carlos de. A prisão do depositário infiel: um ilicito internacional. RT, v. 771. Ano 89, Jan. 2000, p. 7786 e 98-99. Há que se destacar que a Emenda Constitucional n. 45, de 8 de dezembro de 2004 (publicada no D.O.U. em 31 de dezembro de 2004). promoveu alterações importantes no que respeita à consideração dos direitos humanos pela normativa nacional, contribuindo para maior realização e respeito destes direitos.

ARINDT. Hannah. Entre o passado e o futuro. Tradução de Mauro W. Barbosa. São Paulo: Editora Perspectiva, 2001. Ver principalmente: 2. O conceito de História-Antigo é moderno, p. 69-126 e 7. Verdade e Politica. p. 282-325. ARENDT, Hannah. Crises da república. Tradução José Volkmann, São Paulo: Perspectiva. 1973. LAFER, Celso. A mentira: um capítulo das relaçóes entre a ética e a politica. In: VUVAES. Adauto (org.). Etica. São Paulo: Companhia das Letras; Secretaria Municipal de Cultural, 1992, p. $225-237$.

6 Para a última reafirmação do mandato, ver a Resolução da CDH n. 2002/36. Doc. NI': E/CN.4/RES/2002/36, Extrajudicial, summary or arhitray executions. 
especiais, e a consideração dos seus mandatos, métodos de trabalhos e respectivos resultados.

2. O sistema de direitos humanos das Nações Unidas: mecanismos convencionais e extraconvencionais

A consecução de uma cooperação internacional para promover e estimular o respeito aos direitos humanos e às liberdades fundamentais para todos, sem distinção de raça, sexo, lingua ou religião, estabelecida como um dos propósitos das Nações Unidas no parágrafo $3 .^{\circ}$ do art. $1 .^{\circ}$ da sua Carta Constitutiva, conduziu a adoção de medidas que resultaram na instituição de um verdadeiro sistema de direitos humanos em contínuo desenvolvimento. Nos termos do art. 56 da Carta, os Estados-membros das Nações Unidas se comprometem a agir em cooperação com essa organização, em conjunto ou separadamente, para a realização do propósito de respeito universal e efetivo dos direitos humanos e das liberdades fundamentais, conforme previsto na alinea $c$ do art. 55 . Portanto, os Estados-membros têm obrigação de cooperação com o sistema de direitos humanos das Nações Unidas. Ainda na Carta das Nações Unidas, o art. 68 prevê que o Conselho Econômico e Social poderá estabelecer comissões para assuntos econômicos e sociais e para a proteção dos direitos humanos. Na sua primeira reunião em 1946, esse Conselho estabeleceu duas comissões funcionais, compostas por representantes dos Estados: uma referente a direitos humanos e outra relativa ao slatus das mulheres. A CDH foi, assim, criada como um órgão subsidiário do Conselho Econômico e Social. Imediatamente após a sua criação, a $\mathrm{CDH}$ estabeleceu um órgão subsidiário próprio, a Subcomissão para Prevenção de Discriminação e Proteção das Minorias, cuja denominação passou a ser, a partir de 1999, Subcomissão de Promoção e Proteção dos Direitos Humanos. Esse órgão subsidiário, composto por peritos elcitos pelos representantes dos Estados-membros da CDH, possui, inter alia, um mandato para

\footnotetext{
A CDH é composta por representantes de 53 Estados eleitos pelo Conselho Econômico e Social. Em 2004, os representantes dos seguintes Estados compõem a CDH (segue em parênteses o respectivo ano de lérmino do prazo): África do Sul (2006), Alemanha (2005), Arábia Saudita (2006), Argentina (2005). Armênia (2004), Austrália (2005), Áustria (2004), Barcin (2004), Butão (2006), Brasil (2005), Burkina Fasso (2005), Chile (2004), China (2005), Congo (2006), Costa Rica (2006), Croácia (2004), Cuba (2006), Egito (2006), Eritréia (2006). Estados Unidos da América (2005), Etiópia (2006), França (2004), Federação Russa (2006), Gabão (2005), Guatemala (2006), Hungria (2006), Holanda (2006), Honduras (2006), Índia (2006), Indonésia (2006), Irlanda (2005), Itália (2006), Japão (2005), Mauritânia (2006), México (2004), Nepal (2006). Nigéria (2006). Paquistăo (2004), Paraguai (2005), Peru (2006), Catar (2006), Reino Unido (2006), República da Coréia (2004). República Dominicana (2006), Serra Leão (2004). Sri Lanka (2005), Suazilàndia (2005), Sudào (2004), Sućcia (2004), Togo (2004), Uganda (2004), Ucrânia (2005), Zimbábue (2005). . CDH se encontra anualmente por seis semanas em Genebra durante os meses de março e abril.
} 
promover estudos e tecer recomendações com base em suas conclusões, assistindo no empreendimento da reflexão acerca de fenômenos particulares. ${ }^{*}$ A Subcomissão dedicouse nos primeiro anos à preparação de projetos de standards, normas e mecanismos intemacionais para posterior consideração da $\mathrm{CDH}$, muitos dos quais foram posteriormente adotados pela Assembléia Geral das Nações Unidas.

Fsses órgãos subsidiários focaram a codificação e o desenvolvimento do Direito Internacional dus Direitos Humanos em seus trabalhos iniciais. Esse processo resultou na claboração da Carta Internacional dos Direitos Humanos, formada por três elementos: a Declaração Universal dos Direitos Humanos, adotada na forma de resolução pela Assembléia Gcral em 1948; c dois tratados, o Pacto Internacional dos Dircitos ('ivis e Politicos, ${ }^{9}$ e o Pacto Internacional dos Direitos Econômicos, Sociais e Culturais, ambos adotados em 1966, e vigentes a partir de 1976. Vários outros tratados de direitos humanos voltados a assegurar uma proteção especial a grupos particularmente vulneráveis ou contra violações específicas foram com o passar dos anos adotados, e entraram em vigor após a ratificação pelo número solicitado de Estados-partes. Esses tratados compreendem: a Convenção Internacional relativa à Eliminação de todas as Formas de Discriminação Racial (1965, em vigor em 1969), a Convenção relativa à Filiminação de Todas as Formas de Discriminação contra as Mulheres (1979, em vigor em 1981)、 ${ }^{10}$ a Convenção contra a Tortura e Outros Tratamentos ou Penas Cruéis, Disumanos, ou Degradantes (1984, em vigor cm 1987), " a Convenção relativa à Direitos das Crianças (1989, um vigor em

8 A Subcomissão é atualmente composta por 20 peritos, eleitos pela CDH levando em conta a distribuição geográfica, c reúne-se por très semanas em agosto, em Genebra. Membros da Subcomissão de Promoção c Proteção dos Direitos Humanos (2004 2008): Sr. Yozo Yokota, Japão, 2008; Sra. Halima Embarek Warzazi. Marrocos, 2008; Sra. N. U. O Wadibia-Anyanwu. Nigéria. 2008; Sr. Janio Iván Tuñón Veilles. Panamá. 2008; Sr. Soli Jehangir Sorabjee, Índia, 2006; Sr. Abdul Sattar, Paquistão. 2006: Sr. Ibrahim Salama. Egito, 2008; Sr. David Rivkin, Estados Unidos da América, 2008; Sra. Lalaina Rakotoarisoa, Madagascar, 2006; Sr. Paulo Sérgio Pinheiro, Brasil, 2006; Sra. Florizelle O'Connor, Jamaica, 2006; Sra. lulia-Antoanella Motoc, Romênia. 2008; Sra. Kalliopi Koufa, Grécia, 2006; Sr. Vladimir A. Kartashkin. Federação Russa, 2006; Sra. Irançoisc Jane Hampson. Reino Unido, 2006; Sr. Rui Baltazar Dos Santos Alves, Moçambique. 2006; Sr. Emmanuel Decaux, França. 2006; Sra. Chin Sung Chung, República da Coréia. 2008; Sr. Mohammed Habib Cherif, Tunisia, 2008; Sr. Shiqiu Chen, China, 2006; Sr. Marc Bossuyi. Bélgica, 2008; Sr. Gáspár Biró, Hungria, 2008; Sr. José Bengoa, Chile, 2006: Sr. Gudmundur Alfredsson. Islândia, 2008; Sr. Miguel Alfonso Martinez, Cuba, 2008. Ocorre eleição dos membros da Subcomissão na 62. ${ }^{2}$ sessão da CDH (2006) ou na 64. ${ }^{a}$ sessão da CDH (2008).

- O Pacio de Direitos Civis e Políticos conta com dois protocolos facultativos: Protocolo Facultativo ao Pacto de Direitos Civis e Políticos (1966) e o Segundo Protocolo Facultativo visando a abolição da pena de morte (1989).

10 Em 1999, foi adotado o Protocolo Facultativo à Convenção relativa à Eliminação de Todas as rormas de Discriminaçâo contra as Mulheres.

11 Em 2002 foi adotado o Protocolo Facultativo à Convenção contra Tortura e outros Tratamentos ou Penas Cruéis, Desumanos ou Degradantes. 
1990), ${ }^{12}$ e a Convenção Internacional relativa à Proteção dos Direitos de Todos os Trabalhadores Migrantes e Membros de suas Famílias (1990, em vigor em 2003). A esses instrumentos somam-se ainda outros relacionados à proteção da pessoa humana, notadamente normas de Direito Internacional Humanitário, Direito Internacional dos Refugiados e a normativa da Organização Internacional do Trabalho.

Para monitoramento da implementação das disposições previstas nesses instrumentos internacionais foram criados mecanismos, conhecidos por mecanismos convencionais, uma ve que o fundamento jurídico para sua criação pode ser encontrado nos respectivos tratados, com exceção do Comitê relativo aos Direitos Econômicos. Sociais e Culturais, cujo estabelecimento foi previsto por uma resolução do Conselho Econômico e Social. Desse modo, em nivel institucional, sete comitês foram estabelecidos: o Comitê de Direitos Humanos; o Comitê de Direitos Econômicos, Sociais e Culturais; o Comitê contra a Tortura; o Comitê para a Eliminação de Todas as Formas de Discriminação Racial; o Comitê para Crianças; o Comitê para a Discriminação contra a Mulher; e o Comitê para Proteção dos Direitos dos Trabalhadores Migrantes e suas Famílias. Fsses órgãos são compostos por peritos independentes, de competência reconhecida no campo dos direitos humanos, eleitos pelos Estados-partes dos respectivos tratados. Quando um Estado ratifica um tratado internacional de direitos humanos, ele assume a obrigação de implementar suas disposições no âmbito nacional e de submeter relatórios periódicos aos órgãos acima mencionados acerca das medidas tomadas para assegurar a realização dos direitos humanos. ${ }^{13}$ Dois desses órgãos, o Comitê contra Tortura e o Comitê relativo à Eliminação de Discriminação contra as Mulheres podem investigar informações recebidas acerca de violações sistemáticas dos direitos humanos, previstos nos respectivos tratados. Além disso, quatro comitês estabeleceram procedimentos mediante os quais os individuos, vítimas de violação dos direitos estabelecidos nos respectivos tratados perpetrada por um Estado-parte, podem submeter reclamações. Apenas reclamações de pessoas sob a jurisdição de Estados que tenha formalmente aceitado esses procedimentos podem ser examinadas pelos comitês. Em dois casos, a aceitação formal ocorre sob a forma de ratificação de tratados próprios

12 Em 2000, foram adotados dois protocolos facultativos à Convenção relativa aos Direitos da Criança: o Protocolo referente à participação das crianças nos conflitos armados; e o Prolucolo referente ao tráfico de crianças, prostituição infantil e utilização de crianças na pornografia.

1: Os relatórios dos Estados-partes são examinados pelos comitês, juntamente com informações de fontes variadas, na presença de uma delegação do Estado em questão. O exame do relatório culmina na adoçào de observações conclusivas e comentários. em que o comitê apresenta suas ponderações e tece recomendações ao [stado-parte. Os comitês podem também promover interpretações acerca de artigos especificus dos tratados. 
denominados protocolos facultativos, a saher, o Protocolo Facultativo ao Pacto Internacional de Direitos Civis e Políticos e o Protocolo Facultativo à Convenção relativa à Eliminação de Todas as Formas de Discriminação contra as Mulheres. Nos dois outros casos, ou seja, da Convenção Internacional relativa à Eliminação de Discriminação Racial e da Convenção contra a Tortura, a aceitação decorre de declarações especificas feitas pelos Estados, conforme os termos do art. 14 e do art. 22 dos respectivos tratados. A Convenção relativa aos Dircitos dos Migrantes também conta com um procedimento para reclamações (art. 77) e comunicações interestatais (art. 76), que devem contar com declarações específicas dos Estados-partes. ${ }^{14}$

Paralelamente aos esforços de codificação e desenvolvimento do Dircito Internacional no campo dos direitos humanos e respectivo monitoramento do cumprimento das normas convencionais, as Nações Unidas se dedicaram a uma outra forma de sistematização em resposta a violações de direitos humanos. Na estrutura organizacional do sistema de direitos humanos clas Nações Unidas, au lado dos mecanismos convencionais mencionados, identificam-se os mecanismos extraconvencionais, ou seja, em criação prevista nos tratados de direitos humanos. Desde a década de 60 , quando se iniciaram os primeiros passos para a criação dos procedimentos especiais, as Nações Unidas passaram a examinar situações $\mathrm{em}$ países especificos ou temas específicos a partir de uma perspectiva de direitos humanos, mediante mandatos de relatoria voltados a problemáticas de direitos humanos. Os procedimentos especiais desenvolvidos nesse contexto conformam os mecanismos extra-convencionais para direitos humanos das Nações Unidas.

3. O surgimento dos procedimentos especiais e sua inserção no sistema organizacional das Nações Unidas

As violações aos dircitos humanos tornaram-se um desafio à realização dos propósitos das Nações Unidas. No início de sua atuação, havia relutância dos Estadosmumbros em conceder-lhe competências mais amplas em rclação ao tema das violações em razão da consagração do princípio da não intervenção em assuntos internos dos Estados. Em 1947, o Conselho Econômicu e Social adotou uma resolução, que em linhas gerais estabeleceu que a $\mathrm{CDH}$ não tinha poderes para tomar medidas a respeito de quaisquer reclamações relativas a direitos humanos, e resolução reflexiva foi adotada na primeira sessão da $\mathrm{CDH}$ em janeiro de $1947 .^{15}$ Entretanto, esse quadro iniciou sua

\footnotetext{
14 Sobre esses procedimentos, consultar: Doc. NU: Complaint procedures. Human Rights Fact Sheet 1. T/Rev.l.

is PINHEIRO, Paulo Sérgio. Monitorando para a ONU. Politica Fxterna. v. 13, n. 2, 2004, p. $21-22$.
} 
alteração em 1965 com o aumento da pressão para a consideração da problemática de direitos humanos e racismo na África do Sul, quando a $\mathrm{CDH}$ passou a receber várias petições individuais originárias desse país. Diante dessa situação, a CDH considerou a elaboração de procedimentos para tratar de questões relacionadas ao racismo e o tabu foi quebrado somente em 1967, ano em que a (DH, estabeleceu um grupo de trabalho de peritos ad hoc para investigar a situação dos direitos humanos na África do Sul. A demanda inturnacional por ação das Nações Unidas a respeito das violações verificadas naquele país conduziu ao reconhecimento da necessidade de debate público a respeito da situação de determinados países, nos quais violações aos direitos humanos estariam sendo possivelmente cometidas. ${ }^{16}$ Em resposta a um pedido da $\mathrm{CDH}$, o Conselho Econômico e Social adolou a Resolução n. 1.236 (XLII) em 1967, na qual permitiu o exame de casos que revelassem uma situação sistemática de violações de direitos humanos. Nessa esteira, na sua Resolução n. 1.503 (XLVIII), adotada em 27 de maio 1970. o Conselho estabeleceu o que se tornou conhecido por procedimento 1.503 para lidar com reclamações relativas às graves e sistemáticas violações de direitos humanos; que, portanto, cm geral, diz respeito a situações que afetam contingentes populacionais."

A CDH se confrontou com outra situação, após o golpc emprcendido pelo general Augusto Pinochct contra o presidente Allende no Chile em 1973, quando em 1975, estabcleceu um grupo de trabalho ad hoc para investigar a situação de direitos humanos naquele pais. Em 1979, esse grupo de trabalho foi substituido por um relator especial e dois peritos para estudar a questão dos desaparecidos no Chile, constituindo essa iniciativa um importante precedente para a instituição de mecanismos especiais para examinar graves violações de direitos humanos em paises específicos. Em 1980, a CDH, por meio da Resolução n. 20 (XXXVI), estabeleceu o Grupo de Trabalho relativo a Desaparecimentus Involuntários ou Forçados. Em 1982, pela Resolução n. $1.982 / 29$ da

16. A resolução do Conselho Econômico e Social "concedeu à ( omissão e à Subcomissão a autoridade solicitada "para examinar informação relevante a graves violaçōes de direitos humanos e liberdades fundamentais... em todos os paises", c a "fazer um estudo abrangente das situações que revelam um padrāo consistente de violaçōes de direitos humanos". como exemplificado nas situações na República da írica do Sul, o território do Sudoeste da África e Sul da Rodésia" PINHEIRO, Paulo Sérgio. Monitorando para a ONU. Politica Externa, v. 13, n. 2. 2004, p. 30, nota 7.

17 O procedimento 1503 foi revisado em 2000 pelo Conselho Económico e Social por meio da sua Resolução n. $2.000 / 3$, de 16 de junho de 2000, para torná-lo mais eficiente. Embora tenha sido criado em razão de violações referentes a direitos humanos civis e politicos. nada impede que seja usado para a proteção de direitos humanos econômicos, sociais e culturais, com base no princípio da indivisibilidade dos direitos humanos. O procedimento 15113 é adıninistrado pelo Grupo de Trabalho da Subcomissão para Promoção e a Proteção dos Direitos Humanos, composto por cinco peritos. U procedimento 1503 foi utilizado, por exemplo, em relaçào aos conflitos na Chechênia e entrc Israel e Palestina. Sobre esse procedimento ver: TRINDADE, Antônio Augusto Cançado. Direilo das ()rganizaçōes Imternacionais. Belo Horizonte: Del Rey. $2^{\text {a }}$. Edição. 2002, p. 23. Ou Doc. NU: Complaint procedures. Human Rights Fact Sheet n. 7/Rev.l. 
CDH foi estabelecida uma relatoria temática para examinar execuções sumárias e arbitrárias. C'om esses desenvolvimentos, passou a haver menor relutância ao estahelecimento de mecanismos de peritos para lidar com os desafios de direitos humanos em diferentes partes do mundo. Tais procedimentos foram progressivamente aplicados com inovações e adaptados a uma crescente gama de violações. O trabalho dos peritos tornou-se relevante ao possibilitar uma análise. há muito necessária, de como as normas de direitos humanos são aplicadas na realidade e ao construir as bases para um debate informado e substantivo em nivel intergovernamental, iluminado pela experiência de vítimas em geral silenciadas. e indispensável para adoção de medidas concretas a serem umpreendidas para maximizar a proteção dos direitos humanos.

\section{Instauração dos procedimentos especiais}

Os procedimentos especiais podem ser criados por meio de resolução de órgãos das Nações Unidas, tais como o Conselho Econômico e Social, a CDH e a Assembléia Geral, que estabelece o mandato da missão e os critérios de seleção do perito. Em geral, os relatores especiais e representantes da $\mathrm{CDH}$ são selecionados pelo presidente desse órgão, que deve tradicionalmente consultar o seu Bureau, e os representantes do secretário-geral e alguns peritos independentes são selecionados pelo secretário-geral mediante recomendação do Alto Comissário para Direitos Humanos (ACDH). Apesar da ênfase de cada mandato ser diferente, o denominador comum à seleção de todos os peritos é o requisito de que os mesmos sejam individuos de elevada reputação, com conhecimento profundo, habilitados a fornecer serviços de qualidade às Nações Unidas, pelos quais não são remunerados. Os peritos são figuras proeminentes na área de direitos humanos, incluindo antigos e atuais titulares de cargos judiciais, acadêmicos, advogados, economistas, antigos e atuais membros de organizações não-governamentais e antigos membros do staff das Nações Unidas, provindos de diferentes regiões geográficas.

Os peritos lidam com questões cuja dimensão política é bastante marcante. Desse modo, a objetividade e a qualidade do trabalho de alguns deles são algumas vezes questionadas, e há pressão de certos Estados para remover do cargo aqueles que eles consideram muito críticos no que diz respeito a seus registros de direitos humanos; todavia, não há precedentes de que um presidente da $\mathrm{CDH}$ tenha removido qualquer purito. Nessas circunstâncias, assumem imensa relevância a integridade, a independência, a objetividade e a imparcialidade. ${ }^{18} \mathrm{Em}$ casos nos quais o perito é um representante de

'n Conforme observou Paulo Sérgio Pinheiro, a objecividade da avaliaçăo não significa neutralidade. já que algumas vezes os relatores especiais podem após ponderar o estado dos fatos decidir denunciar os abusos cometidos. Em suas palavras: Vós podemos concluir que o principio da imparcialidade contradiz uma 
algum governo, o mesmo deve conduzir seu trabalho independentemente de qualquer influência governamental ou não-governamental. ${ }^{19}$ Com efeito, a independência é uma condição sine qua non para o cumprimento com êxito dos mandatos. Essa independîncia deve ser entendida em relação à missão conforme descrita no mandato do perito, bem como deve ser equilibrada com a posição da CDH que analisa o trabalho dos peritos, tendo em mente que os mesmos são irremoviveis e independentes. Durante 1999-2000, a $\mathrm{CDH}$ empreendeu uma revisão geral do trabalho dos peritos e como resultado adotou várias resoluções em abril de 2000 , visando a fortalecer a efetividade do trabalho dos peritos. As medidas adotadas incluíram o estabelecimento de um prazo limite para os titulares dos mandatos e a reafirmação de que a independência dos peritos constitui o principal critério para a sua seleção. ${ }^{20}$

\section{O status jurídico dos peritos na estrutura das Nações Unidas}

Os titulares dos mandatos possuem diferentes títulos, tais como relator especial, representante especial ou perito independente, que constituem o resultado de negociações politicas e não refletem. de modo algum. uma hierarquia nem uma indicação dos poderes a eles confiados. Não obstante essa diversificação, todos eles são juridicamente considerados como um perito em missão (expert on mission) nos termos da

avaliação pessoal do problema durante uma missão. Se os relatores especiais testemunham uma situação consisteme de alegaçồs de graves violações de direitos humanos, execuções sumárias, tortura. ou atos de genocidio, nós devemos denunciá-las e não nos limitar a documentar discretamente. Entretanto. essa é uma importante decisão tática. Nessa decisão pesam o privilégio de acesso e a naturiza do mandato que envolve avaliação dos fatos e não questũes políticas. apesar de em muitos casos a fronteira entre essas duas perspectivas não serem muito claras, principalmente em paises que sofrum de instabilidade politica. PINHI:IRO, Paulo Sergio. Musings of a UN Special Rapporteur on Human Rights. Global Governance, $\mathrm{n}$. 9, 2003, p. 11.

19 Doc. UN: E/CN.4/2000/112. Report of the Inter-sessional Working Group on Enhancing the Effectiveness of the Mechanisms of the Commission on Human Rights. § 7-10. A indicação de relatores originários da mesma região na qual será desempenhado o mandato é bastante criticada, como se percebeu, por exemplo, na 58. da $\mathrm{CDH}$, quando o grupu africano insistiu em apontar pelo nome o titular do mandato na resolução relativa a racismo, contrariamenti aos procedimentos estabelecidos. Independentemente dos méritos do candidato, a iniciativa foi criticada pela sociedade civil em razão das implicações de se criar um precedente e de ameaçar a autonomia das indicações. PINHEIRO, Paulo Sergio. Musings of a I N Spccial Rapporlüur on Human Rights. Global Governance. n. 9, 2003, p. 8.

20 Até 1999, um perito poderia servir indefinidamente em um mandato na medida em que o mandato estivesse em operação. No entanto, a CDH decidiu que os peritos deveriam servir um termo máximo de seis anos, sendo possivel uma extensão de três anos adicionais como medida transitória para aqueles peritos cujo tenno de seis anos já houvesse terminado. A CDH também decidiu que deveria haver uma mudança nos peritos que serviam nos grupos de trabalho, a ser cumprida em medidas incrementais durante um periodo de três anos de transição: uma substituição de dois membros no primeiro ano, dois no segundo e um no terceiru ano forneceria continuidade durante o periodo transitório. Doc. UN: E/CN.4/2000/112, Report of the Int:rsessional Working Group on Enhancing the Effectiveness of the Mechanisms of the Commission on Human Rights, $§ 20$. 
Convenção das Nações Unidas rulativa a Privilégios e Imunidades, adotada pela Assembléia Giral em 1946, em reflexo ao parágrafo 3..$^{\circ}$ do art. 105 da Carta das Nações Unidas. ${ }^{21}$ As disposições da mencionada Convenção foram incorporadas por referência a centenas de acordos relativos às Nações ('nidas e suas atividades, sendo que a seção 22 do art. VI prevê o seguinte:

Art. 17 Peritos em missão para a Organização das Nações Unicas

Secção 22 Os peritos (com exchusão dos funcionários referidos no art. $V$ ) que se encontrem no desempenho de missões por conta da Organização das Naçôes Unidas gozam, durante o periodo de duração da missão, incluindo o tempo da viagem, dos privilégios e imunidades necessários ao exercicio das suas funções com total independência. Gozam em especial dos privilégios e imunidades seguintes:

a) Imunidade de prisão ou de detenção da sua pessoa e de apreensão das suas bagagens pessoais:

b) Imunidade de qualquer procedimento judicial no que diz respeito aos atos por eles praticados no decurso das suas missões (incluindo as suas palavras e escritos). Esta imunidude continuará a ser-lhes concedida mesmo depois de estas pessoas terem cessado de desempenhar missóes para a Urganização das Nações Unidas:

c) Inviolabilidade de todos os papéis e documentos:

d) Direito de fazer uso de códigos e de receber documentos e correspondencia por correio ou por mulas seladas, para as suas comunicações com a Organizaşão das Nações Unidas:

e) As mesmas facilidades, no que diz respeito as regulamentações monetárias ou de câmbio, que as que são

Art. 105 .

1. A organização gozará. no território de cada um de seus membros. dos privilégios e imumidades necessários à realização de seus propósitos.

2. Os representantes dos membros das Nações Unidas e os funcionários da Organização gozarão. igualmente dos privilégios e das imunidades necessários ao exercicio independente de suas funções relacionadas com a Organizaçào

3. A Asrembléia Geral poderá fazer recomendações com o fim de determinar os pormenores da aplicação dos \$\$ 1." "e 2." deste artigo ou poderá propor aos membros das Nações Unidas convenções nesse sentido.

Em aplicação dos mandamentos do parágrafo $3^{\circ}$ do art. 105, foram adotados os seguintes matados multilaterais entre os Estados-partes, negociados sob a égide das Nações Unidas: a Convenção rélativa a Privilégios e Imunidades das Naçóes Lnidas, subscrita em 13 de fevereiro de 1946, por ocasião da Assembléia Geral das Nações Unidas em Londres, e a Convenção relativa a Privilégios e Imunidades das Agências Especializadas das Nações Unidas, adotada pelos Estados-membros. em Nova York, a 21 de novembro de 1947. Tais Convenções foram assinadas pelo Brasil, aprovadas pelo Congresso Nacional e promulgadas, respectivamente pelo Decreto n. 27.784 de 16 de fevereiro de 1950 a pelo Decreto n. 63.151 de 22 de agosto de 1968. A Convenção de 1946 foi aprovada pelo Congresso Nacional pelo Decreto Legislativo 4, de 13 de fevereiro de 1948. O Instrumento brasilciro de ratificaçào foi depositado no Secretariado das Naçôes Unidas, em Lake Success, Nova York. a 15 de dezcmbro de 1949. 
concedidas aos representantes de governos estrangeiros em missão oficial temporária;

f) As mesmas imunidades i facilidades, no que diz respeito às suas bagagens pessoais, que as que são concedidas aos agentes diplomáticos.

Para o esclarecimento da natureza de seu status jurídico em razão da aplicabilidade da disposição acima mencionada aos relatores, peritos independentes e representantes de direitos humanos, no sentido dos termos empregados na Convenção e das conseqüências então decorrentes, foram de imensa relevância dois pareceres consultivos da Corte Internacional de Justiça (CIJ). A seção 30 do art. VIII da Convenção prevê que as diferenças surgidas da interpretação ou aplicação da Convenção devem ser referidas a CIJ, que decidirá definitivamente. ${ }^{22} \mathrm{O}$ Conselho Econômico e Social pode apresentar pedido de parecer consultivo à CIJ, com fundamento no parágrafo $2 .^{\circ}$ do art. 96 da Carta das Nações Unidas ${ }^{23}$ e em conformidade com a Resolução da Assembléia Geral n. 89 (I) de 11 de dezembro de 1946, que autorizou ao Conselho solicitar pareceres consultivos da CIJ acerca de questões relativas ao escopo de suas atividades, podem ser resumidos como segue. Em 1989. a CIJ analisou a aplicabilidade da seção 22 do art. VI da Convenção a relatores da Subcomissão; e em 1999. foi analisado um caso específico de aplicabilidade da imunidade de jurisdição, nos termos da alínea $b$ seção 22 do art. Vl a um relator da $\mathrm{CDH}$.

22 Arl. VIII - Resolução de diferenças

Secção 29 - A Organização das Nações Unidas deverá prever modos de resolução apropriados para:

a) As diferenças em matéria de contratos ou outras diferenças de direito privado nas quais a Organização seja parte:

b) As diferenças nas quais esteja envolvido um funcionário da Organização que, èm virlude da sua situação oficial. goze de imunidude. no caso de essa imunidade não ter sido levantada pelo Secretúriogeral.

Seç̧̃̃o 30 Qualquer diferença decorrente da interpretação ou aplicação da presente Convenção será apresentado à Corte Internacional de Justiça, a menos que. mum determinado caso, as partes acordem no recurso a um outro meio de resoluçăo. Se surgir uma diferença entre a Organização das Nações Unidas. por um lado, e um membro, por outro, será pedido um parécer subre todos os pontos de direito envolvidos, em confurmidade com o art. 96 da Carta e o art. 65 do Estatuto da Corte. O parecer da Corte será aceite ${ }^{23}$ Art. 96 pelas parles como decisivo.

(...)

2. Outros órgãos das nações linidas e entidades especializadas, que forem em qualquer época devidamente aulorizados pela Assemblèia Geral poderão lambèm solicilar parecens consultivos da Corle sobre questões juridicas surgidas dentro da esfera de suas atividades. 
a) Parecer consultivo da CIJ de 15 de dezembro de 1989: Aplicabilidade da seção 22 do art. VI da Convenção das Nações Linidas relativa a Privilégios $c$ Imunidades $^{24}$

Conforme a Resolução do Conselho Econômico e Social n. 1.989/75. de 24 de maio de 1989, que solicitou o parecer a CIJ, havia uma diferença entre as Nações Unidas c o Governo da Romênia quanto à aplicabilidade da Convenção de 1946 a Dumitru Mazilu, o relator especial da Subcomissão para Prevenção da Discriminação e Proteção de Minorias. Mazilu, nacional romeno, teve, de 13 de março de 1984 a 29 de agosto de 1985, o stants de membro da Subcomissão; de 29 de agosto de 1985 a 31 de clezembro de 1987, ele foi membro e relator da Subcomissão accrca da situação de direitos humanos e jovens; e finalmente, após a última data, ele permaneceu somente como relator especial. Em momentos desse periodo, Mazilu adoeceu, ausentando-se por algum tempo de suas funções. Contudo, já recuperado, ele passou a não ter acesso às comunicações enviadas pelas Nações Unidas. Além disso, o relator registrou a recusa do Governo da Romênia em conceder-lhe permissão para viagens e a pressão exercida sobre ele e sua família para que se afastasse da relatoria das Nações Unidas. E:m 15 de agosto de 1988. a Subcomissão adotou a decisão 1988/102, pela qual solicitou que o secretário-geral procurasse o Governo da Romênia e ressaltasse a necessidade de estabelecer contatu pessoal com o relator, Mazilu, pedindo sua localização e a permissão de viagens e outras facilidades para o desempenho de sua função.

A posição do Governo da Romênia foi de que qualquer intervenção das Nações L'nidas e qualquer forma de investigação seriam consideradas uma interferência nos assuntos internos do país. Em 1. ${ }^{\circ}$ de setembro de 1988, a Subcomissão adotou a Resolução n. 1.988/37, pela qual, inter alia. solicitou ao secretário-geral que abordasse uma ve $\iota$ mais o governo romeno e invocasse a aplicabilidade da Convenção das Naçôes Unidas relativa a Privilégios e Imunidades (1946), e se houvesse divergência quanto à aplicabilidade, a CDH deveria solicitar ao Conselho Fconômico e Social que levasse a diferença à jurisdição consultiva da CIJ. Segundo os argumentos da Romênia, o problema da aplicação da Convenção não emergia no caso em questão, pois, a Convenção não igualava relatores, cujas atividades são apenas ocasionais, a peritos em missões para as Nações Unidas; e que mesmo se aos relatores fosse concedido um status de peritos, eles poderiam gozar apenas de privilégios e imunidades funcionais previstos pela Convenção

24 Doc. CIJ: Applicahility of article VI, section 22, of the Convention on the Privileges and Immunities of th' United Nations, Advisory Opirion of 15 December 1989. A composição da CIJ foi a seguinte: Presidente Ruda; Juiers Lachs, Elias, Oda, Ago. Schwebel, Jennings, Bedjaoui, Ni, Evensen, Tarassov, Guillaume. Shahabuddeen and Pathak. Os juizes Oda. Evensen e Shahabuddeen apensaram pareceres separados ao parecer consultivo. 
aplicáveis apenas no momento em que partissem para uma viagem conexa com a performance de sua missão. Por fim, alegaram limitações desses privilégios e imunidades no país de nacionalidade do perito. Verificada a diferença, em 6 de março de 1989, a CDH adotou a Resolução n. 1989/37, ra qual recomendou que o Conselho Econômico e Social solicitasse um parecer consultivo da CIJ. Conforme o parecer da Corte, Mazilu nunca deixou de ter o status de perito em missão nos termos da seção 22 ou deixou de estar intitulado ao gozo dos privilégios e imunidades para exercício de suas funções. A seção 22 do art. VI da ('onvenção aplicava-se, portanto, no caso de Mazilu como um relator especial da Subcomissão.

Nesse parecer, a C.IJ abordou nos parágrafos 40-52 o significado da disposição relevante da Convenção, considerando primeiramente o sentido da expressão peritos em missões, que conforme observou não é definida pela Convenção. A seção 22 esclarece que os funcionários das Nações Unidas, mesmo se escolhidos em consideração de sua experlise técnica em um campo particular, não são incluídos na categoria de peritos nos termos da disposição comentada. Somente peritos desempenhando missões para as Nações Unidas estão cobertos pela disposição, que, no entanto, não-fornece nenhuma indicação da natureza, duração ou local dessas missões. Nem os travaux préparatoires pertinentes fornecem maiores orientações a este respeito. A CIJ decidiu que o propósito da seção 22 é permitir às Nações Unidas confiar missões a pessoas que não possuam o status de seu funcionário e garantir a essas pessoas os privilégios e as imunidades que sejam necessários para o exercício independente de suas funções. A CIJ observou também que muitos comitês, comissões ou órgãos similares cujos membros servem, não como representantes dos Estados, mas em razão de sua capacidade pessoal, têm sido estabelecidos pelas Nações IInidas. Em todos esses casos, a prática da Organização mostra que as pessoas apontadas, e em particular os membros desses comitês e comissões, têm sido considerados como peritos em missões nos termos da seção 22. Em relação ao significado da frase durante o periodo de duração da missão, incluindo o tempo da viagem, a ClJ analisou o sentido da palavra missão em inglês (mission) e cm francîs (mission), as duas línguas nas quais a Convenção foi adotada, e constatou que a palavra se referia inicialmente a uma tarefa confiada a uma pessoa somente se essa pessoa fossu enviada a algum lugar para desempenhá-la. No entanto. a palavra adquiriu um significado mais amplo e passou a abranger as tarefas confiadas a uma pessoa. independentemente dessas tarefas envolverem viagens. Esse segundo sentido. mais amplo. foi o consagrado pela C.IJ, que ressaltou que enquanto alguns peritos precisam necessariamente viajar para desempenhar suas tarefas, outros podem desempenhá-las sem ter que viajar. Em ambos os casos, a seção 22 é aplicável com o intuito de assegurar a independência de tais peritos no 
interesse das Nações Unidas, assegurando-lhes privilégios e imunidades necessários para esse propósito.

Outro importante ponto analisado foi se os peritos em missões podem invocar os privilégios e as imunidades previstos na seção 22 contra os Estados dos quais são nacionais ou no território dos quais eles residam. A CIJ notou que a seção 15 da Convenção prevê que os termos das seções 11,12 e 13, do art. IV, relativas aos representantes dos Estados-membros, ${ }^{25}$ não são aplicáveis a um representante $\iota$ às

Art. H-Representante's dos membros

Sieçiōo 11 - Us representamtes dos membros junto dos órgãos principais e suhsidiários das Nações Unidas e nas cunfereincias convocadas pelas Naçòes l'nidas gozam, durante o exercicio das suas funções e no décurso de viaguns com destino co local da runiăo ou no regresso dessa reunião, dos privilégios $e$ imunidades seguintes:

a) Imunidade de prisão ou de dereņ̧ão da sua pessoa e de apreensão da sua bagagem pessoal, bem como, no qui rispita aos atos por cles praticados na sua qualidade de representantes (incluindo as suas palavrus e cscritos), imunidade de qualquer procedimento iudiciul,

b) Inviolahilidade' de lodos os papéis e documentos:

c) Direitu de utilizar códigos e de expedir e receber documentos ou a correspondencia por correio ou malas seladas:

d) Iseņ̧ão para si próprios e para os seus cônjuges relativamente a todas as medidas restritivas da imigração. lodas as formalidades de registro de estrangeiros e todas as obrigações de serviço nacional nos paise's por eles visitados ou atravessados no exercicio das suas funções;

e) As mesmas fucilidades no que diz respeito às restriçōes monetárias ou cambiais que as concedidas aos representantes de governos estrangeiros em missão oficial temporária:

f) As mesmas imunidades e facilidades no que diz respeitu às suts bagagens pessoais qut as cuncedidas aos agentes diplomáticos; e ainda

g) Qualquer outro privilégio, imunidade e facilidade, que não sejam incompativeis com as disposiçóes supra. de que gozem os agentes diplomáticos, salvo o direito de pédir isenção de impostos alfandegarios sobre bens imporlados (para além dos que fazem parte das suas bagagens pessoais) ou de impostos indiretos ou tributos sobre a venda.

Seç̧ão 12 - Com vista a assegurar aos representantes dos membros. nos órgãos principais e subsidiários das Naçôes Unidas e nas conferências convocadas pela Organização, uma total liberdade de expressão e uma completa independência no exercicio das suas funções, a imunidad' de qualquer procedimento judicial. no que respeila às suas pa!avras e escritos ou aos alos por eles praticados no exercicio das suas funçòes. continuará a ser-lhes concedida mesmo depois de estas pessoas terem deixado de ser os representantes dos membros.

Seç̧ão 13 No caso em que a incidencia de um imposıo dependa da residência do sujeito, os periodos duranti os quais os representantes dos membros junto dos órgãos principais e subsidiários das Naçòes Unidas. bem como nas conferências convocadas pela Organização das Nações Unidas, se encontrem no territorio de um Fistado membro para o exercicio das suas funçôes nâo serâo considerados como periodos de residencia.

Seç̧ão 14 Os privilégios e imunidades são concedidos aos representantes dos membros não para seu proveito pessoal, mas, com o fim de assegurar, com toral independência, o exercicio das suas funçöes relacionadas com a Organização. Por conseguinte, um membro tem não apenas o direito, mas também o dever de levantar a imunidade do seit representante em todos os casos em que, em sua opinião, a imunidad pudesse impedir que fosse feira justiça e desde que ela possa ser levantada sem prejuizo do fim para que foi concedida.

Seç̧ão 15 - As disposições das seç̧ões 11,12 e 13 não são apliciuveis tratando-se de um representanti' em relação às autoridades do Estado de que é nacional ou de que é ou foi o representante.

Secção lo Para os fins do presente artigo. considera-se que o termo "representantes» inclui todos os delegados, delegados-adjuntos, conselheiros, perritos técnicos e secretários de delegação. 
autoridades do Estado do qual ele é um nacional ou do qual ele é ou tem sido representante, e observa que o art. V, relativo a funcionários das Nações Unidas, ${ }^{26}$ e o art. VI, relativo a peritos em missões para as Nações Unidas, não contêm nenhuma disposição comparável. Assim, a CIJ considerou que essa diferença de abordagem explica-se pelo fato de os privilégios e as imunidades dos arts. V e VI serem conferidos com vista a assegurar a independência de funcionários e peritos internacionais no interesse das Nações Unidas; e que essa independência deve ser respeitada por todos os Estados. incluindo o Estado de nacionalidade e o Estado de residência. A CIJ observou, ainda, que alguns Estados-partes da Convenção fizeram reservas a certas disposições do art. V e do art. VI a respeito de seus nacionais uu pessoas residentes em seus territórios. Nessa perspectiva, o fato de ter-se sentido a necessidade de fazer essa reserva confirma que na ausência das mesmas, os peritos em missões gozam de privilégios e imunidades. previstos na Convenção, em suas relações com os Estados dos quais eles sejam nacionais ou nos

26 Art. V-Funcionários

Seç̧ão 17 O Secreláriu-geral determinara us catcgornus de funcionários aos quais se aplicam as disposições do presente artigo. bem como do ar. VII. A lista surá por ele submetida à Assemhléia Geral $e$ em seguida comunicada aos governos de todos os membros. Os nomes dos funcionários incluidos nestas categorias serão periodicamente comunicudos aos governos dos membros.

Seç̧ão 18 - Os funcıonários da Organização das Nações L nidas:

a) Gozarão da imunidade de qualquer procedimento judicial relativamente aos atos por eles praticados oficialmente (incluindo as suas palauras e escritos):

b) Estarão isentos de qualquer imposto sobre os salários a emelumentos pagos pela Organização das Naçōes Unidas:

c) Estarão isentos de qualquer obrização relativa au serviço nacional;

d) Não estarão sujeilos, assim como os seus cônjuges e os membros da sua familia que se encontrem a seu cargo, às disposições que restringem a imigração e às formalidades de registro de estrangeiros;

e) Gozarão, no que diz respeilo às facilidades de cambio, dos mesmos privilégios que os funcionários de categoria equivalente pertencentes às missões diplomáticas acreditadas junto do governo em questão,

1) Gozarão, assim como os seus cônjuges e os membros du sua familia que se encontrem a seu cargo, das mesmas facilidades de repartiamento que os enviados diplomáticos em periodo de crise internacional,

g) Gozarão do direito de imporlar. livre de encargos. o seu mobiliário e objetos pessoais por ocasião da primeira vez que iniciou funçóes no pais em questão.

Seç̧ão 19 Para além dos privilégios e imunidades previstos na seç̧ão 18. o Secretário-geral e todos os subsecretirios-gerais, tanto no que thes diz respeito como em relação aos seus conjuges e filhos menores, gozarão dos privilégios. imunidades. isençōes e facilidades concedidos, $\mathrm{cm}$ conformidade com o direito internacional, aos enviados diplomáticos.

Seç̧ão 20 Os privilégios e imunidades sào concedidos aos funcionários unicamente no interesse das Nações Unidas e não para seu proveito pessoal. O Secretário-geral poderá é deverá levantar a imunidade concedida a um funcionário em lodos os casos em que. em sua opiniäo. essa imunidade pudesse impidir qu fosse feita justiça e desde que ela possa ser levantada sem prijuizo para os meresses da Organização. Relativamente ao Secretário-geral. o Conselho de Segurança tem iompetência para pronunciar u levantame'nto das imunidades.

Seç̧ão 21 A Organização das Nações Unidas colahorará. em todus as ocusiōes, com as auroriciades competentes dos Estados membros com vista a facilitar a boa administraçâo da justiçu, assegurar a observância dos regulamentos de polícia e evitar qualquer abuso a que poderiam dar lugar os privil 's.ros. imunidades e facilidades enumerados no presente artigo. 
territórios dos quais eles residam. Em suma, a seção 22 da Convenção é aplicável a pessoas, que não funcionários das Nações Unidas, as quais uma missão tenha sido confiada pela Organização e que são, pois, intituladas a gozar dos privilégios e das imunidades previstos nessa seção com vista ao exercício independente de suas funções. Durante todo o período das missões, os peritos gozam desses privilégios e imunidades funcionais, estejam eles viajando ou-não; e esses privilégios e imunidades podem ser invocados contra o Estado de nacionalidade ou de residência a menos que uma reserva à seção 22 da Convenção tenha sido validamente feita pelo Estado.

A aplicabilidade da mencionada disposição da Convenção aos relatores especiais da Subcomissão foi especificamente analisada nos parágrafos 53-55 do parecer. A CIJ enfatizou que a situação dos relatores da Subcomissão se relaciona à posição jurídica dos relatores em geral, sendo de grande importância para o sistema das Nações Unidas, e observou que na Resolução n. 1.983/32, de 27 de maio de 1983, do Conselho, ressaltou-se a questão de que os membros da Subcomissão deveriam ser eleitos pela CDH como peritos em razão de sua capacidade individual. A CIJ então decidiu que desde que seu slatus não seja correspondente ao de um funcionário das Nações Unidas, e desde que eles desempenhem independentemente funções contempladas em seu mandato, os membros da Subcomissão devem ser considerados como perito em missões nos termos da seção 22. Além disso, a CIJ observou que, em conformidade com a prática seguida por muitos órgãos das Nações Unidas, a Subcomissão tem de tempo em tempo apontado relatores ou relatores especiais com a tarefa de estudar temas especificos. Apesar desses relatores serem normalmente selecionados entre os membros da Subcomissão, havia casos em que eles não eram membros ou concluíam seu relatório após a expiração do prazo de seu status de membro da Subcomissão. A CIJ conclui que desde que o status do relator da Subcomissão não seja de um representante de um Estado-membro nem de um funcionário das Nações Unidas, e desde que eles desempenhem tal investigação independentemente no interesse das Nações Unidas, eles devem ser considerados como peritos em missões no sentido da seção 22, mesmo quando eles não são, ou-não mais são, membros da Subcomissão. Assim, eles gozam, de acordo com aquela seção, dos privilégios e imunidades necessários para o exercício de suas funções.

b) Parecer consultivo da CIJ de 29 de abril de 1999: Diferença relativa à Imunidade relacionada a Processo Judicial em face de um Relator especial da $\mathrm{CDH}^{27}$

Doc. CIJ: Difference Relating to Immunity from Legal Process of a Special Rapporteur of the Commission on Human Rights, Advisory Opinion of 29 April 1999. Composiçào da Corte: Presidente: Schwebel; Vice- 
Esse parecer consultivo da CIJ foi solicitado pela Decisão 1.998/197, de 5 de agosto de 1998, do Conselho Econômico e Social das Nações Unidas. Essa decisão demonstra a existência de uma diferença entre as Nações Unidas e o Governo da Malásia, nos termos da seção 30 da Convenção das Nações Unidas relativa a Privilégios e Imunidades de 1946, a respeito da imunidade em relação a processo judicial de Dato'Param Cumaraswamy, o relator especial da CDH para independência dos juízes e advogados. O cerne da questão era a aplicabilidade da seção 22 do art. VI da citada Convenção ao caso específico desse relator, levando em conta as circunstâncias estabelecidas nos parágrafos $1 .^{\circ}$ a 15 da nota do sccretário-geral a respeito dos privilégios e imunidades do relator especial da $\mathrm{CDH}$ para independência dos juízes e advogados ${ }^{28} \mathrm{e}$ as obrigações jurídicas da Malásia nesse caso. A decisão solicitou ainda que o Governo da Malásia assegurasse que todos os julgamentos e processos em curso perante os tribunais da Malásia ficassem pendentes, aguardando o recebimento do parecer consultivo da CIJ, que deveria ser aceito como decisivo para as partes, conforme os termos da Convenção de 1946.

A Convenção foi estipulada para, inter alia, proteger diferentes categorias de pessoas. incluindo Peritos em Missão pura as Nações Linidas, de todos os tipos de interferência pelas autoridades nacionais. Ėm particular, nos termos da alínea $b$ da seção 22 do art. VI, os peritos em missão devem gozar de privilégios e imunidades necessários para o exercicio independente de suas funções durante o periodo de suas missões, em particular, a imunidade em relação a processo judicial de qualquer tipo a respeito de palavras faladas ou escritas e atos desempenhados por eles no curso da performance de suas missões. Essa imunidade continua a vigorar não obstante as pessoas envolvidas não estejam mais designadas em missões para as Nações Unidas. Em 1994. a CDH indicou Cumaraswamy, um jurista nacional da Malásia, como relator especial para independência dos juizes e advogados. cujo mandato incluía. inter alia, investigar alegações substanciais e identificar e registrar ameaças à independência do judiciário, advogados e oficiais de tribunais. A CDH, em abril de 1997, renovou seu mandato para um periodo adicional de três anos. Em razão de um artigo intitulado Justiça da Malásia em julgamento, publicado com base em uma entrevista dada pelo relator especial a um periódico International Commercial Litigation em novembro de 1995, duas companhias comerciais na Malásia afirmaram que o artigo continha palavras difamatórias que provocaram escândalo público,

Presidente: Weeramantry; Juizes: Oda, Bedjaoui, Guillaume, Ranjeva. Herczegh. Shi. lleischhauer, Koroma, Vereshchetin. Higgins, Parra-Aranguren, Kooijmans, Rezck; Registrar Valencia-Ospina. 
ódio é desprezo. Cada uma dessas companhias instaurou um processo em face do relator por danos no montante de aproximadamente US\$ 12 milhões cada um deles.

O Conselho Jurídico das Nações Unidas considerou as circunstâncias da entrevista e das passagens controvertidas do artigo e curtificou que Cumaraswany foi entrevistado em sua função como relator especial, que o artigo claramente se referia a essa função e ao mandato global do relator para investigar alegações a respeito da independência do judiciário e que as passagens citadas eram relativas a tais alegações. Em 15 de janeiro de 1997. o C'onselhu Jurídico em uma nota verbal solicitou às autoridades competentes da Malásia que prontamente levassem au conhecimento dos tribunais nacionais a questão da imunidade de jurisdição do relator. Em 20 de janeiro de 1997, o relator peticionou junto à Corte Superior de Kuala Lumpur (onde corriam os processos contra ele) para afastar as queixas com fundamento no fato de que as palavras que foram objeto dos processos foram faladas por ele no curso de sua missão para as Nações I Inidas. Em 7 de março de 1997, o secretário-geral apresentou uma nota, confirmando isses pontos i reforçando que Cumaraswamy era imune em relação a processo judicial fundado nessas palavras; nota essa que deveria ser submetida à Corte Superior. Um certificado foi escritu pelo ministro das Relações Exteriores da Malásia e enviado à Corte Superior, mas não se referiu à nota do secretário-geral que afirmava a imunidade do relator em razão das atividades praticadas no escopo de seu mandato. Em 28 de junho de 1997, o juiz competente da Corte Superior de Kuala Lumpur concluiu que o relator não era protegido pela imunidade que alegava, que a nota do secretário-geral era meramente uma opinião com pouco valor probatório e sum força mandatória para a Corte Superior e que o certificado do ministro de Relações Fxteriores era apenas um pronunciamento acerca de um estado de fatos pertinentes ao status e ao mandato do réu como relator especial.

Em julho de 1997, o Conselho Jurídico solicitou an Governo da Malásia que intervisse no processo para que os encargos financeiros da defesa fossem assumidos pelo governo. O Conselho Jurídico se referiu às disposições de solução de diferenças surgidas da interpretação e aplicação da Convenção de 1946, estabelecidas na seção 30 , e que se o governo decidisse que não poderia proteger o relator especial, consideraria que uma diferença quanto ao sentido das disposições teria surgido entre as Nações Unidas e o Governo da Malásia. Outros processos foram iniciados em face do relator c o secretáriogeral enviou uma nova nota cum o mesmo teor da anterior e se comunicou com o ministro de Relações Exteriorus. Em 7 de novembro, o sucretário-geral informou o Governo da Malásia acerca da diferença e da possibilidade de levá-la ao conhecimento da CIJ. Em 19 de fevereiro de 1998, não obteve sucesso a apelação do relator. O Secretário Gcral apontou uma enviada especial, Marie Yves Fortier, do Canadá, que não conseguiu 
resolver a questão e o caso foi levado à CIJ. A CIJ fez referência ao caso Mazilu (1989) no qual havia estabelecido a aplicabilidade da seção 22 do art. VI ao rulator especial da Subcomissão. A CIJ decidiu que a mesma conclusão deveria ser aplicada a respeito do relator especial apontado pela $\mathrm{CDH}$. Os relatores especiais da $\mathrm{CDH}$, em geral, não desempenham apenas missões de pesquisa como a maioria dos relatores da Subcomissão, também têm a tarefa de monitorar violações de direitos humanos e relatá-las; no entanto, o decisivo é a atribuição de uma missão pelas Nações Unidas, e, como peritos em missão, eles devem gozar de privilégios c imunidades nos termos da seção 22, que asseguram o exercício independente de suas funções. As disposições se aplicavam a Cumaraswamy, que como relator especial é um pırito em missão, figura essa que goza de privilégios e imunidades previstos na Convenção de 1946 nas suas relações com os Estados-partes, incluindo o Estado do qual é nacional ou residente.

A C'IJ ressaltou que no processo de determinar se um perito particular em missão deve gozar da imunidade prevista na alínea $b$ da seção 22 , o secretário-geral das Nações Unidas tem um papel decisivo. A seção 23 do art. VI ${ }^{29}$ da Convençào prevê que os privilégios e as imunidades são conferidos aos peritos nos interesses das Nações Unidas e não para o benefício pessoal dos próprios individuos. Ao exercer a proteção dos peritos das Nações Unidas, o secretário-geral protege a missão atribuída ao perito. Assim, o secretário-geral como chefe administrativo da Organização tem autoridade e responsabilidade para exercer a proteção dos interesses das Nações Unidas e dos seus agentes, incluindo os puritos em missão. Determinar se um agente da organização agiu no curso da performance de sua missão depende dos fatos do caso particular. No caso de Cumaraswamy, o secretário-geral, ou o Conselho Juridico em seu nome, informou em numerosas ocasiões ao Governo da Malásia sua decisão de que Cumaraswamy havia pronunciado as palavras citadas no artigo em sua função de relator especial e quc, conseqüentemente, estava investido de imunidade jurisdicional em relação a tais palavras. Além disso, o contato dos relatores especiais com a mídia tornou-se prática padrão, e como o relator não extrapolou seu mandato, a Convenção se aplica a ele.

Portanto, o secretário-geral tem responsabilidade de assegurar os interesses das Nações Unidas, ¿ cabc a ele avaliar se seus agentes atuaram no escopo de suas funções c, quando concluir positivamente, proteger os agentes, incluindo os peritos em

29 Art. VI-Peritos em missão para u Organizução das Nações Unidas

Seç̧ão 23 Os privilégios e imunidades são concedidos aos peritos no interesse da Organizaçio das Nações Unidas e não para seu proveito pessoal. O Secríário-geral poderá e deverá levantar a imunidade concedida a um perito em todos os casos em que, em sua opinião. essa imunidade pudesse impudir que fosse feita justiça e desde que ela possa sùr levantada sem causar prejuizo aos interesses da Organização. 
missões, afirmando sua imunidade. Isso significa que o secretário-gural tım autoridade e responsabilidade de informar o governo de um Fstado-membro de sua decisão e, quando apropriado. solicitar que o governo atue conforme a mesma, e, em particular, solicitar que o governo leve suas decisões ao conhecimento dos tribunais locais no evento de algum processo involvendo os atos ou palavras de seus agentes. A decisão do secretário-geral cria uma presunção de imunidade que pode ser afastada somente por fortes razões e deve ser devidamente considerada pelos tribunais nacionais. As autoridades governamentais de um Estado-parte à Convenção de 1946 têm a obrigação de fornecer tal informação aos tribunais nacionais, já que a correta aplicação da Convenção pelos mesmos depende dessa informação. O não-cumprimento dessa obrigação pode resultar na instituição de procedimentos nos termos da seção 30 do art. VIII da Convenção. A Corte concluiu que o Governo da Malásia tinha a obrigação, nos termos do art. 105 da Carta e nos termos da Convenção de 1946, de informar seus tribunais da posição tomada pelo secretário-geral. De acordo com uma norma de Direito Internacional, a conduta de qualquer órgão de um Estado deve ser considerada cono um ato do Estado. Como o governo não transmitiu a decisão do secretário-geral aos tribunais competentes e o ministro de Relações Exteriores não se referiu à mesma em seu próprio certificado, a Malásia não cumpriu com a obrigação acima mencionada. ${ }^{30}$

A alínea $b$ da seção 22 da Convenção explicitamente estabelece que os peritos em missão devem gozar de imunidade de jurisdição em relação a palavras faladas ou escritas e atos feitos por eles no curso da performance de sua missão. Por implicação necessária, questões de imunidade são questões preliminares. Fsse é um princípio de Direito reconhecido amplamente, e a Malásia tem obrigação de respeitá-lo. Os tribunais da Malásia não decidiram in limine litis acerca da imunidade do relator especial. anulando a essência da norma de imunidade de jurisdição da alínea $b$ da seção 22. Além disso, o processo acarretou encargos a Cumaraswamy. Como mencionado, a conduta de um órgão de um Estado, mesmo de um órgão independente do poder executivo, deve ser considerada como um ato do Estado. Conseqüentemente, a Malásia não agiu em

30 Conforme ressaltou o juiz Resek $\mathrm{cm}$ parecer separado, a obrigaçào da Malàsia nào è meramente notificar os tribunais nacionais a respeito da decisăo do Secretário-geral, mas é tambćm assegurar que a imunidade seja respeitada. O governo assegurará o respcito à imunidade se utilizar todos os meios a sua disposição em relação ao judiciário de forma a ter a imunidade aplicada, do mesmo mudo que cle defenderia seus próprios interesses e posiçōes perante os tribunais. O juiz. Weeramantry. por sua vez ressaltou em parecer separado que caso se considere um tribunal doméstico livre para não considerar a determinaçào do Secretário-geral sobre s imunidades dos puritos, muitos problemas surgiriam em relação à atividade das Nações Unidas em várias áreas. Segundo elc. hả também necessidade de uniformidade na jurisprudência relativa a essa matéria. independentemente das funçð̋es particulares de um relator. uma vez que não é propicio à evolução de um sistema uniforme de Direito Intemacional Administrativo que os relatores possam ter diferentes privilégios dependendo de scu mandatu. 
conformidade com suas obrigações do Direito Internacional. Por força da seção 30 do art. VIII da Convenção de 1946, o parecer dado pela CIJ deve ser aceito como decisivo pelas partes em disputa. Já que o relator é um perito em missão, ele goza de imunidade em relação a processos judiciais nos termos da aliena $b$ da seção 22, e o Governo da Malásia tem obrigação de comunicar o parecer consultivo aos tribunais nacionais competentes, de forma que as obrigações internacionais da Malásia tenham efeito e a imunidade de Cumaraswamy scja respeitada.

\section{Os mandatos dos peritos}

Desde a criação dos mecanismos de procedimentos especiais de direitos humanos das Nações Unidas sua atuação e estrutura se expandiram consideravelmente. Os mandatos dos procedimentos especiais podem ser relacionados à situação dos díreitos humanos em paises específicos ou podem abordar temas particulares relacionados aos direitos humanos, daí se falar $\mathrm{em}$ mandatos relativos a paises (country mandates) e mandatos temáticos (thematic mandates), e são exercidos com o apoio do Escritório do $\mathrm{ACDH}{ }^{31}{ }^{3}$ Em geral, os mandatos relativos a países são revisados anualmente pela $\mathrm{CDH} \mathrm{e}$ os mandatos temáticos são revisados a cada três anos. Para que o mandato continue, a CDH adota uma resolução em que renova o mandato e identifica seu escopo. Após sua ação na África do Sul em 1967, a CDH passou a lidar com situações de direitos humanos em países especificos.

Em 2004. pode-se identificar os seguintes mandatos relativos a paises: $:^{32}$ (i) Perito Independente para a situação dos direitos humanos no Afeganistão; ${ }^{33}$ (ii) relator

"Em 20 de dezembro de 1993, a Assembléia Geral criou o cargo de Alto Comissário de Direitos Humanos $(\mathrm{ACDH})$ das Nações Unidas. Diferentemente dos peritos, o $\mathrm{ACDH}$ é um luncionário de alto escalào das Nações Unidas, apontado pelo Secretário-geral c aprovado pela Assembleiia Geral, que chefia o Escritório do $\mathrm{ACDH}$, o qual, por sua vez, confere suporte ao trabalho dos peritos. Não se deve confundir as posições: enquanto os mandatos dos peritos săo específicos, focando um pais ou um tema, y mandato do ACDH é amplo, incluindo a promoção e a proteção de todos os direitos humanos, civis, culturais, econômicos, políticos e sociais em todas as partes do mundo. Não obstante, a distinção, há muita interação entre o ACDH c os peritos, e mesmo possibilidade de coincidência entre os mandatos do ACDH e dos procedimentos especiais, que deve ser evitada por meio de coordenação.

32 Entre os mandatos que foram recentemente extintos constam: Guiné Equatorial (1979-2002); Guatemala (1982-1996); República Islâmica de Irã (1984-2002); Nigéria (1997-1999): Ruanda (1994-2001); Sudão (1993-2003): Território da Antiga lugoslávia (1992-2001): Bósnia e Herzegóvina e República Federal da lugoslávia (2001-2003).

33 Mandato estabelecido em 1984 pela Resolução n. 1.984/37 do Conselho Econômico e Social. como Relator Especial da $\mathrm{CDH}$ para a situação dos direitos humanos no Afeganistão. Na última runovação em 2003. por meio da Resolução da CDH n. 2.003/77. alterou-se para Perito Independente. A posição foi atribuida ao Sr. Cherif Bassiouni (Egito). e o mandalo foi estendido por um ano, conforme estabelecido pelo Presidente da 
especial para a situação dos direitos humanos em Belarus; ${ }^{34}$ (iii) relator especial da $\mathrm{CDH}$ para a situação dos direitos humanos no Burundi: ${ }^{35}$ (iv) representante especial do secretário-geral para a situação de direitos humanos no Camboja; ${ }^{36}$ (v) Pcrito Independente sobre a situação dos direitos humanos no Chade; ${ }^{37}$ (vi) Representante Pessoal do $\mathrm{ACDH}$ para a situação de direitos humanos em Cuba; ${ }^{38}$ (vii) Perito Independente apontado pelo secretário-geral para a situação dos direitos humanos no Haiti; ${ }^{39}$ (viii) relator especial da $\mathrm{CDH}$ para a situação dos direitos humanos no Iraque; ${ }^{40}$ (ix) Perito Independente para serviços de cooperação técnica e consultoria na Libéria; ${ }^{41}(x)$ relatur especial da $\mathrm{CDH}$ para a situação dos dircitos humanos em Myanmar; ${ }^{42}$ (xi) relator especial da CDH para a situação dos direitos humanos na República Democrática do Congo (ex-Zaire) $;^{43}$ (xii) relatur especial para a situação de direitos humanos na República do Povo Democrática da Coréia $;^{44}$ (xiii) Perito Independente apontado pelo secretário-

CDH cm 21 de abril de 2004. Os peritos anteriores foram: Sr. Kamal Hossain (Bangladesh/1998-2003); $\mathrm{Sr}$. Choong Ilyun Paik (República da Coréia/1995); e Sr. Felix Ermacora (Áustria/1984).

34 Mandato estabelecido em 2004 pela Resolução n. 2.004/14 da $\mathrm{CDH}$, sem duração especifica. sendo indicado o Sr. Adrian Severin (Romênia) como relator.

35 Mandato criado em 1995 pela Resolução da CDH n. 1.995/90. A última renovação ocorreu em 2003 por meio da Resolução da $\mathrm{CDH}$ n. 2.003/16. Relatores: Sra. Marie-Thérèse Aissata Këita-Bocoum (Còte d'Ivoire/1999); Sr. Paulo Sérgio Pinheiro (Brasil/1995). Em 2004, a Resolução n. 2.004/82 promoveu algumas alterações no mandato. scm previsão especifica de duração, sendo o atual perito o Sr. Akich Akola (Quênia).

it) Mandato criado em 1993 pela Resolução da $C D H$ n. 1.993/6 e renovado pela Resolução da CDH n. 1.995/55, sem duração especifica. Relatores: Sr. Peter Leuprecht (Áustria/2000): Sr. Thomas Hammarberg (Suécia/1996); Michacl Kirby (Austrália/1993).

37 Mandato criado em 2004 pela Resolução n. 2.004/85 da CDH cum previsão de duração de um ano. Relatora: Sra. Mônica Pinto (Argentina).

${ }^{38}$ Mandato criado em 2002 pela Resolução n. 2.002/18 da CDH. sem duração especifica. Relatora: Sra. Chrisstine Chanet (França).

39 Mandato criado em 1992 pela Resolução da CDH n. 1.992/77; alterado pela Resolução da CDH n. 1.995'70. Relatores: Sr. Louis Joinet (França/2002); Sr. Adama Dieng (Sencga//1995); Marco Túlio Bruncelli (Itália/1992).

40 Mandato criado em 1991 pela Resolução da CDH n. 1.991/74. Relatur atual: Sr. Andreas Mavrommatis (Chipre/1999).

41 Mandato criado em 2003 pela Resolução da CDH n. 2.003/ 82 por um prazo de três anos. Relatora: Sra. Charlotte Abaka (Gana/2003).

42 Mandato criado em 1992 pela Resoluçào da CDH n. 1.992'58. Renovação em 2003 por meio da Resolução da $\mathrm{CDH}$ n. 2.003/12, e em 2004 pela Resolução n. 2.004/61 por um prazo de um ano. Relatores: Sr. Paulo Sérgio Pinheiro (Brasil/2000); Sr. Raj Soomer Lallah (Mauricius/1996); Sr. Yozo Yokota (Japão/1992).

43 Mandato criado em 1994 pela Resolução da $\mathrm{CDH}$ n. 1.994,87: Renovação em 2003 pela Resolução da CDH n. 2.003/15, e em 2004 pela Resolução n. 2.004/84 sem duração especifica. Relatores: Sr. Titinga Frédéric Pacéré (Burkina Faso/2004). Sra. Iulia-Antoanella Motoc (Romènia/2001); Sr. Roberto Garreton (Chile//994).

4. Mandato criado em 2004 pela Resolução n. 2.004/13, sem duração específica. Relator: Sr. Vitit Muntarbhorn (Tailàndia). 
geral para a situação dos direitos humanos na Somália; ${ }^{45}$ (xiv) Perito Independente para a situação de direitos humanos no Sudão; ${ }^{46}(x v)$ relator especial da CDII para a situação dos direitos humanos nos territórios palestinos ocupados desde $1967 ;^{47} \mathrm{e}$ (xvi) Perito Independente para a situação de direitos humanos no Uzbequistão (procedimento 1503). ${ }^{48}$

Os mandatos temáticos abarcam temas variados a respeito dos direitos civis, políticos, econômicos, culturais e sociais. Percebe-se que no início desses procedimentos havia uma tendência em se considerar os direitos civis e políticos, no entanto. recentemente. atenção tem sido amplamente conferida aos direitos econômicos, sociais e culturais. Entre os mandatos temáticos em operação em 2004 figuram os seguintes: ${ }^{49}$ (i) relator especial da $\mathrm{CDH}$ para execuções extrajudiciais, sumárias ou arbitrárias; ${ }^{50}$ (ii) relator especial da CDH para a questão de tortura; ${ }^{51}$ (iii) relator especial da CDH para intolerância religiosa (liberdadu de religião ou crença); ${ }^{52}$ (iv) relator especial da $C D H$ para uso de mercenários como meio de impedir o exercício do direito dos povos a autodeterminação; ${ }^{53}$ (v) relator especial da CDH para tráfico de crianças, prostiluição e

45 Mandato criado em 1993 pela Resolução n. 1.993/86 da CDH. Renovado em 2004 pela Resolução CDH $n$. 2.004/80 por um período de um ano. Relatores: Sr. Ghanim Alnajjar (Kuwaiv/2001); Sra. Mona Rishmaur (Palestina/1996); Sr. Mohamed Charfi (Tunisia/1995); Sr. Fanuel Jariretundu Kozo (1993).

$\therefore$ Mandato criado pela Decisão n. 2.004/128 do Conselho Econômico c Social por um período de um ano. Relator: Sr. Emmanuel Akwei Addo iGana).

17 Mandato criado pela Resolução da CDH n. 1993/2 A. Relatores: Sr. John Dugard (África do Sul/2001): Sr. Giorgio Giacomelli (ltália/1999); Sr. Ilannu Halinen (Finlândia/I995); Sr. René Felber (Suiça/1993).

t. Mandato criado pela decisão adotada em 31 de março de 2004 por um periodo de um ano no contexto do procudimento especial $1503 \mathrm{da} \mathrm{CDH.} \mathrm{Relator:} \mathrm{Sr.} \mathrm{Latif} \mathrm{Huseunov} \mathrm{(Azerbaijāo).}$

12. Recentemente foram extintos os seguintes mandatos temáticos: Direito à restituição, compensação e ruabilitação para as vitimas de graves violações de direitos humanos e liberdades fundamentais (1998-2000); (Os efeitos da divida externa sobre o pleno gozo dos direitos econômicos, sociais e culturais (1998-2000); Perito Independente da CDH para examinar a estrutura internacional criminal e de direitos humanos ixistente para a proteção das pessoas em relação a desaparecimentos involuntários ou forçados (200) 2002/CDH 2001 46): Perito Independente da CDH para examinar a questão de redação de um protocolo opcional ao Pacto Internacional de D reitos Econômicos, Sociais e Culturais (2001-2003/( DH/2001/30).

Mandato criado em 1982 pela resolução 1982/35 do Conselho Econômico e Social: renovação em 200I pela risolução 200li45 da CDH e em 2004 pela resolução 2004/37 da CDH por um periodo de três anos. Relatores: Sr. Philip Alston (Austrália/2004); Sra. Asma Jahangir (Paquistão/I998).

51 Mandato criado em 1985 por meio da resulução $1985 / 33$ da CDH; renovação em 200। pela resolução da $\mathrm{CDH}$ 2001/62, e em 2004 pela resoluçĩo da CDH 2004/41 por um periodo de três anos. Relatores: Sr. Manfred Nowak (Áustria/2004 - aguardando aceitação do mandato); Sr. Nigel Rodley (Reino Unido/1943): Sr. Theo C. van Boven (Holanda/200l).

52 Mandato criado em 1986 pela resolução da CDH 1986/20; renovação em 2001 pela resolução 2001/42 da $\mathrm{CDH}$, e em 2004 pela resolução da CDH 2004/36 por um período de três anos. Relatores: Sra. Asma Jahangir (Paquistão/2004): Sr. Abdelfattah Amor (Tunísia/1993).

53 Mandato criado em 1987 pela resoluçäo da CDH 1987/16; renovação em 2001 pela resolução 2001/3 da CDH e em 2004 pela resolução da CDH $2004 / 5$ por um periodo de três anos. Relatores: Sra. Shaista Shameen (Fiji/2004); Sr. Enrique Bemales Ballesteros (Peru/1987). 
pornografia relacionadas a crianças; ${ }^{54}$ (vi) Representante do secretário-geral para pessoas internamente deslocadas; ${ }^{55}$ (vii) relator especial da $\mathrm{CDH}$ para promoção e proteção do direito à liberdade de opinião e expressão; ${ }^{56}$ (viii) relator especial da $\mathrm{CDH}$ para formas contemporâneas de racismo. discriminação racial, xenofobia e intolerância relacionada; ${ }^{57}$ (ix) relator especial da $\mathrm{CDH}$ para independência dos juizes e advogados; ${ }^{58}(x)$ relator especial da $\mathrm{CDH}$ para violência contra mulheres, suas causas e conseqüências; ${ }^{59}$ (xi) relator especial da $\mathrm{CDH}$ para efeitos adversos do movimento ilícito e do depósito de produtos tóxicos e produtos perigosos e lixos sobre o gozo dos direitos humanos; ${ }^{60}$ (xii) Perito independente da CDH para direito ao desenvolvimento (e Mecanismos de followup) $;^{61}$ (xiii) Perito Independente da CDH para direitos humanos e pobreza extrema; ${ }^{62}$ (xiv) relator especial da $\mathrm{CDH}$ para direito à educação; ${ }^{63}(x v)$ relator especial da $\mathrm{CDH}$ para direitos humanos dos imigrantes; ${ }^{64}$ (xvi) relator especial da $\mathrm{CDH}$ para direito a alimentos; ${ }^{65}$ (xvii) Representante Especial do secretário-geral para a situação dos

54 Mandato criado em 1990 pela resolução da $\mathrm{CDH}$ 1990/68; renovação em 2001 pela resolução da $\mathrm{CDH}$ 2001/75. e em 2004 pela decisão do Conselho Econômico e Social 2004/285 por um periodo de três anos. Relator: Sr. Juan Miguel Petit (Uruguai/2001).

ss Mandato criado em 1992 pela resolução da $\mathrm{CDH}$ 1992/73; renovaçăo em 2001 pela resolução da $\mathrm{CDH}$ 2001/54, e em 2004 estabelecimento de novo mandato pela resolução 2004/55 da CDH por um período de dois anos. Relatores: Sr. Walter Kälin (Suiçai2004); Sr. Francis Deng (Sudão/1992).

56 Mandato criado em 1993 pela resolução da CDH 1993/45; última renovação em 2002 pela resolução da ('DH 2002/48. Relatores: Sr. Abid Hussain (India/ I993); Sr. Ambeyi Ligabo (Quênia/2002).

57 Mandato criado em 1993 pela résolução 1993/20 da CDH; última renovação em 2002 pela resolução 2002/68 da CDH. Relatorus: Sr. Maurice Glèglèahanhanzo (Benin/1993); Sr. Doudou Diène (Senegal/2002).

58 Mandato criado em 1994 pela resoluçāo da CDH 1994/41; última renovação em 2003 pela resolução da CDH 2003/43, por um periodo de três anos. Relatores: Sr. Param Cumaraswamy (Malásia/1994); Sr. Leandro Despouy (Argentina/2003).

59 Mandato criado em 1994 pela resolução da CDH 1994/45; última renovação em 2003 pela resolução da CDH 2003/45, por um periodo de três anos. Relatores: Sra. Radhika (coomaraswamy (Sri Lanka 1994); Sr. Yakin Ertürk (Turquia/2003).

60 Mandato criado em 1995 pela Resolução da CDH n. 1.995/81; renovação em 2001 pela Resolução da CDH 2.001/35, e em 2004 pela Resolução da $\mathrm{CDH}$ n. 2.004/17, por um período de três anos. Relatores: Sr. Okechukwu Ibeanu (Nigéria/2004); Sra. Fatma Zohra Ouhachi-Vesely (Argélia/1995).

61 Mandato criado pela Resolução da CDH n. 1.998/72; última renovação em 2001 pela Resolução da CDH n. 2.001/9. Relator: Sr. Arjun Sengupla (India/1998-2004). O destino dos mecanismos acerca do direito ao desenvolvimento está sendo atualmente discutido na $\mathrm{CDH}$.

62 Mandato criado em 1998 pela Resolução da CDH n. 1.998/25; renovação em 2002 pela Resolução $n$. 2.002/30e em 2004 pela Resolução n. 2.004/23 por um periodo de dois anos. Relatores: Sr. Arjun Sengupta (Índia/2004); Sra. Anne-Marie lizin (Bélgica'1998).

63. Mandato criado em 1998 pcla Resolução da CDH n. 1.998/33; renovação em 2001 pela Resolução da CDH n. 2.001/29. e em 2004 pela Resolução n. $2.004 / 25$ por um periodo de três anos. Relatores: Sr. Vernor Muñoz Villalobos (Costa Rica 2004i; Sra. Katarina Tomasevski (Croácia/1998).

64 Mandato criado em 1999 pela Resolução da CDH n. 1.999/44: última renovação em 21102 pela Resolução da $\mathrm{CDH}$ n. 2.002/62. Relatura: Sra. Gabriela Rodriguez Pizarro (Custa Rica/1999).

65 Mandato criado em 2000 pela Resolução da CDH n. 2.000/10: última renovação em 2003 pela Resolução da $\mathrm{CDH}$ n. 2.003/25. Relator: Sr. Jean Ziegler (Suiça/2000). 
defensores de direitos humanos; ${ }^{66}$ (xviii) relator especial da CDH para moradia adequada como um componente do dirsito a um padrão adequado de vida; ${ }^{67}$ (xix) Perito Independente da $\mathrm{CDH}$ para políticas de ajuste estrutural e dívida extema; ${ }^{0 \%}(x x)$ relator especial da $\mathrm{CDH}$ para a situação dos direitos humanos e das liberdades fundamentais dos povos indigenas; ${ }^{69}$ (xxi) Representante Especial do secretário-geral para crianças e conflito armado; ${ }^{70}$ (xxii) relator especial para direito ao gozo do mais elevado standard atingivel de saúde física e mental; ${ }^{71}$ (xxiii) relator especial para tráfico de pessoas, especialmente mulheres e crianças; ${ }^{72}$ (xxiv) Perito Independente para assistir o ACDH na realização do mandato descrito na Resolução da CDH n. 2004/87 intitulada "Proteção de direitos humanos e liberdades fundamentais no combate ao terrorismo"; 73 e (xxv) Perito Independente apontado pelo secretário-geral para atualizar o conjunto de princípios para a proteção e a promoção de direitos humanos por meio do combate à impunidade. ${ }^{74}$

Os mandatos são usualmente confiados a um perito individual. Em alguns casos, entretanto, devido à natureza e à complexidade da questão em considerada, a CDH estabelece um grupo de trabalho de peritos, que são em geral compostos de cinco indivíduos, nacionais de cada um dos grupos regionais das Nações Unidas: África. Ásia, América Latina e Caribe, Europa Oriental e o grupo Ocidental. Nos últimos anos, as relações entre direitos humanos e desenvolvimento alcançaram evidência. Assim, conseqüentemente, o direito ao desenvolvimento e as questões de ajuste estrutural passaram a receber atenção adicional, sendo criado um mecanismo de follow-up, composto de um perito independente e um grupo intergovernamental de trabalho. Além desse mecanismo, deve-se ressaltar os seguintes grupos de trabalho em operação em 2004:

66 Mandato criado em 2000 pela Resolução da CDH n. 2.000/61; última renovação em 2003 pela Resolução da $\mathrm{CDH}$ n. 2.003/64. Relator; Sra. Hina Jilani (Paquistão/2000).

67 Mandato criado em 2000 pela Resolução da CDH n. 2.000/9; última renovação em 2003 pcla Resolução da $\mathrm{CDH}$ n. 2.003/27. Relator: Sr. Miloon Kothari (Índia/2000).

68 Mandato criado em 2000 pela Resolução da $\mathrm{CDH}$ n. 2.000/82 e Decisão da $\mathrm{CDH}$ n. 2.000/109: última renovação em 2003 pela Resolução da $\mathrm{CDH}$ n. 2.003/21. Relatores: Sr. Bernards Andrew Nyamwaya Mudho (Quênia/2001); Sr. Fantu Cheru (EUA/Etiópia/2000). Houve entre 1998-2000 um mandato denominado Perito Independente para politicas de ajuste estrutural.

69 Mandato criado em 2001 pela Resolução da CDH n. 2.001/57, e renovado em 2004 pela Resolução da $\mathrm{CDH}$ n. 2.004/62 por um periodo de três anos. Relator: Sr. Rodolfo Stavenhagen (México/2001).

70 Mandato criado pela Assembléia Geral. Relator: Sr. O Otunnu.

71 Mandato criado em 2002 pela Resolução da CDH n. 2.002/31. Relator: Sr. Paul Hunt (Nova 7.lândia/2002).

72 Mandato criado $\mathrm{em} 2004$ pela Resolução da $\mathrm{CDH}$ n. 2.004// 10, por um periodo de très anos. Relatora: Sra. Sigma Huda (Bangladesi/2004).

73 Mandato criado em 2004 pela Resolução n. 2.004/87 da CDH por um periodo de um ano. Perito: Sr. Robert K. Goldman (Estadus Unidos da América).

74 Mandato criado em 2004 pela Resolução n. 2.004/72 da CDH por um periodo de um ano. Perito: Sra. Diane Orentlicher (Estados Unidos da Américar2004). 
(i) Grupo de Trabalho para desaparecimentos involuntários ou forçados; "(ii) Grupo de Trabalho para detenção arbitrária; ${ }^{76}$ (iii) Grupo de Trabalho Intergovernamental, com o seguinte mandato: $(a)$ tecer recomendações voltadas à implementação efetiva da Declaração de Durban e seu Programa de Ação; (b) preparar standards internacionais complementares para fortalecer e atualizar os instrumentos internacionais contra racismo. discriminação racial, xenotobia e intolırância relacionada um todos seus aspectos; ${ }^{77} \mathrm{e}$ (iv) Grupo de Trabalho de Peritos Independentes para estudar os problemas de discriminação racial enfrentados pelos povos de descendência africana. ${ }^{8}$

$\mathrm{Na}$ Subcomissão há seis grupos de trabalho encarregados dos seguintes temas: comunicações (reclamações). formas contemporâneas de escravidão, populações indigenas, minorias. administração da justiça e corporações transnacionais. Além desses mandatos, os estudos previstos em mandatos designados a peritos particulares englobam temas tais como: (i) Povos indigenas e sua relação com a terra; ${ }^{79}$ (ii) Glubalização e seu impacto no pleno gozo dos direitos humanos; ${ }^{80}$ (iii) O conceito e a prática da ação afirmativa: ${ }^{81}$ (iv) Os direilos dos não ciladãos; ${ }^{82}$ (v) Práticas tradicionais que afetam a saúde das mulheres e da menina; ${ }^{\diamond 3}$ (vi) Terrorismo e direitos humanos; ${ }^{84}$ (vii) Dircitos

75 Mandato criado em 1980 pela Resolução da CDIl n. 20 (XXXVI): renovação em 2001 pela Resolução da CDH n. 2.001/46, e em 2004 pela Resolução n. 2.004/40, por um periodo de três anos. Peritos atuais: Sr. Joel Adebayo Adekanye (Nigéria/2000); Sr. Santiago Corcuera Cabezut (México/2004); Sr. Darhi Göttlicher (Croácia/2004); Sr. Siephen J. Toope (Canadá/2002); Sr. Saied Rajaic Khorasani (República Islâmica do Irã/2003).

76 Mandato criado em 1991 pela Resolução da CDH n. 1.991/42; última atualização em 2003 pela Resolução da $\mathrm{CDH}$ n. 2.003/3I, por um período de três anos. Peritos atuais: Relator-presidente: Sra. Leila Zerrougui (Argélia/2001); Sra. Soledad Villagra de Biedermann (Paraguai/2000); Sr. Tamás Ban (Hungria/2001); Sr. Seyed Mohammad Hachemi (República Islâmica do Irã/2002): Sra. Manuela Carmema Castrillo (Espanha/2003).

77 Mandato criado em 2002 pela Resolução da CDH n. 2.002/68, aguardando indicação de peritos.

78 Mandato criado em 2002 pela Resolução da CDH n. 2.002/68, e renovado em 2003 pela Resuluçào $n$. 2.003/30, por um periodo de três anos. Peritos: Sr. Peter Lesa Kasanda, Relator Presidente (Zâmbia/2002); Sr. George N. Jabbour (República Árabe Síria/2002): Sr. Roberto B. Martins (Brasil/2002); Sr. Joe Frans (Suécia/2004); Sra. Irina Zlatescu (Romènia/2004).

79 Mandato previsto na Resolução da Subcomissão n. 2.000/108. Perita: Sra Daes. Relatórios: 48. ${ }^{3}$ sessão (1997) E/CN.4/Sub.2/AC.4/1996/2; E/CN.4/Sub.2/AC.4/1996/2/Add.1: 53.” sessào (2001)

E/CN.4/Sub.2/2001/21.

80 Mandato prevista na Resolução da Subcomissão n. 1.999/8. Peritos: Sr. Oloka-Onyango c Sra.Udagama. Relatório: $52 .^{3}$ sessão (2000) - E/CN.4/Sub.2/2000/13.

81 Mandato previsto na Decisão da CDH n. $1.999 / 107$ e Resolução da Subcomissão n. 1.998/5. Perito: Sr. Bossuyl. Relatório: 52. ${ }^{a}$ sessão (2000) - E/CN.4/Sub.2/2000/11 and Corr.1.

82 Mandato previsto na Decisão da $\mathrm{CDH}$ n. 2.000/104 e na Decisão da Subcomissão n. 2.000/103. Perito: Sr. Weissbrodt. Relatórios: 53." sessão (2001) - E/CN.4/Sub.2/2001/20; E/CN.4/Sub.2/2001/20/Add.l.

83 Mandato previsto na Resolução da $\mathrm{CDH}$ n. $1.999 / 80$ e Resoluções ns. 2.000/10 e 2.001/13 da Subcomissão. Perita: Sra. Warzazi.

${ }^{84}$ Mandato previsto na Decisão da CDH n. $1.998 / 107$ e na Decisão da Subcomissão n. 2.001/18. Perita: Sra. Koufa. Relatório: 51. ${ }^{a}$ sessão (1999) - E/CN.4/Sub.2/1999/27. 
humanos e responsabilidades humanas; ${ }^{85}$ (viii) Metodologia e o trabalho do Fórum Social; ${ }^{86}$ (ix) Evolução da administração da justiça por meio de tribunais militares, ${ }^{87}(x)$ Discriminação no sistema de justiça criminal; ${ }^{8 R}$ (xi) Escopo das atividades e responsabilidades das forças armadas, da polícia civil, dos funcionários civis internacionais e dos peritos das Nações Unidas que participam de operações de paz; ${ }^{89}$ (xii) Métodos de trabalho e atividades das corporações transnacionais; ${ }^{90}$ (xiii) Necessidade de desenvolver princípios orientadores sobre a implementação das normas e standards existentes de direitos humanos no contexto da luta contra a pobreza extrema; ${ }^{91}$ (xiv) A não-discriminação conforme prevista no parágrafo $2 .^{\circ}$ do art. $2 .^{\circ}$ do Pacto Internacional de Direitos Econômicos, Sociais e Culturais; ${ }^{92}(x v)$ O retorno dos bens dos refugiados ou das pessoas deslocadas; ${ }^{{ }^{3} 3}$ (xvi) As abordagens construtivas e pacíficas para situações envolvendo minorias, ${ }^{94}$ (xvii) Soberania permanente dos povos indigenas sobre recursos naturais ${ }^{95}$ (xviii) A discriminação baseada no trabalho e na descendência em outras regiões do mundo: ${ }^{96}$ (xix) Reservas a tratados de direitos humanos; ${ }^{97}$ (xx) A Declaração Universal relativa ao Genoma Humano e Direitos Humanos como a contribuição da Subcomissão para as reflexões do Comitê Internacional de Bioética no follow-up da Declaração Universal; ${ }^{98}$ (xxi) Medidas previstas nos vários instrumentos internacionais de direitos humanos para a promoção e a consolidação da democracia $;{ }^{99}$ (xxii) Avaliando a utilidade, o escopo e a estrutura de um estudo sobre os perigos reais e potenciais ao gozo efetivo de direitos humanos, decorrentes de testes, produção, transferência, tráfico ou uso de armas de destruição em massa, ou com efeito indiscriminado, ou de natureza que cause dano supérfluo ou sofrimento desnecessário, incluindo o uso de armas contendo urânio

85 Mandato previsto na Resolução da CDH n. 2.000/63 e na Decisão da Subcomissão n. 2.000/111. Relator: Sr. Alfonso Martinez. Relatório: 58. ${ }^{a}$ sessão da CDH (2002) - E/CN.4/2002/107. Mandato previsto na Resolução da Subcomissão n. 2.001/24. Perito: Sr. Bengoa.

Mandato previsto na Decisão da Subcomissão n. 2.001/103. Perito: Sr. Joinet.

Mandato previsto na Decisão da Subcomissão n. 2.001/104. Perita: Sra. Zerrougui.

Mandato previsto na Decisão da Subcomissão n. 2.001/105. Perita: Sra. Hampson.

Mandato previsto na Resolução da Subcomissão n. 2.001,3. Peritos: Sr. Eide c Sr. Weissbrodt.

Mandato previsto na Resolução da Subcomissão n. 2.001/8. Peritos: Sr. Pinheiro. Sr. Yokota. Sr.Guissé e Sr Bengoa.

92 Mandato previsto na Resolução da Subcomissão n. 2001/23. Perito: Sr. van Hoof

93 Mandato previsto na Decisão da Subcomissão n. 2001/122. Perito: Sir. Pinheiro.

44 Mandato previsto na Resoluçào da Subcomissão n. 2001/9. Perito: Sr. Eide.

95 Mandato previsto na Resolução da Subcomissão n. 2001/10. Perita: Sra. Daes.

96 Mandato previsto na Decisão da Subcomissão n. 2.001/110. Perito: Sr. Goonesekere. Relatório: 53. ${ }^{a}$ sessão (2001) - E/CN.4/Sub.2/2001/16.

97 Mandato previsto na Resolų̧ão da Subcomissão n. 2.001/17. Perita: Sra. Hampson. Relatório: 51. ${ }^{x}$ sesssão (1999) - E/CN.4/Sub.2/1999/28 and Corr.1.

98 Mandato previsto na Decisão da Subcomissão n. 2.001/113. Perita: Sra. Motoc.

99 Mandato previsto na Decisão da Subcomissão n. 2.001/1/4. Perito: Sr. Rodriguez-('uadros. Relatório: 53." sessāo (2001) - E/CN.4/Sub.2/2001/32. 
enriquecido: ${ }^{10 n}$ (xxiii) A questão do comércio e transporte de armas pequenas e leves e do uso de tais armas no contexto das normas de direitos humanos e humanitárias; ${ }^{101}$ e (xiv) Promoção da realização dos direitos a beber água e a esgoto. ${ }^{102}$

7. Métodos de trabalho dos peritos

Não-obstante as resoluções que estabelecem os mandatos adotarem linguagem diferente ao descrevê-los, há certa uniformidade quanto aos métodos de trabalho dos peritos, independentemente dos mandatos previstos. Com efeito. com o acúmulo de experiência, os peritos desenvolveram abordagens e metodologias específicas para realizar seus mandatos. Por recomendação da Conferência de Direitos Humanos de Viena (1993), desde 1994 acontecem reuniões anuais dos agentes de procedimentos especiais das Nações Unidas. Em 1999, na sexta reunião anual de peritos foi aprovado um manual, denominado Manual para Relatores Especiais/Represintantes/Peritos e Presidentes dos Grupos de Trabalho dos Procedimentos Especiais da Comissão de Direitos Humanos e do Programa de Serviços de Consultoria $;{ }^{103}$ que inter alia descreveu em detalhes os seus métodos de trabalho. Em regra. todos os peritos relatam a órgãos intergovernamentais, tais como a $\mathrm{CDH}$ ou a Assembléia Geral a respeito de suas verificações, conclusões e recomendações. $O$ mandato de alguns peritos demanda que desempenhem estudos conceituais enquanto outros abrangem uma abordagem mais prática. Os peritos pesquisam e estudam questões relevantes aos direitos humanos, empreendem visitas aos países, recebem e consideram reclamações de vítimas de violações de direitos humanos e representam-nas em contatos com os governos; e, em alguns casos, também recomendam programas de cooperação técnica. Alguns peritos, ao receberem informação de alegações específicas de violações de direitos humanos ou quando uma grave violação de direitos humanos parece ser eminente, enviam apelos urgentes ao governo envolvido. Os peritos relatam suas atividades, em geral à C.DH. seguindo os princípios de transparência e consistência, e devem procurar oferecer oportunidades iguais as fontes de informação c ao Governo em questão. Nos casos em que se identifiquem vários tipos de violaçõus relativas aos mandatos de diferentes peritos, esses são estimulados a coordenar suas ações. O conhecimento da violação ou uma investigação promovida pelas Nações Unidas acerca das circunstâncias de um caso

100 Mandato previsto na Decisão da Subcomissão n. 2.001/119. Perito: Sr. Sik Yuen.

101 Mandato previsto na Decisão da Subcomissão n. 2.001/120. Perita: Sra. Barbara Frey.

102 Mandato previsto na Resolução da Subcomissão n. 2.001/2. Perito: Sr. Guissé.

103 Manual for Special Rapporteurs/Representatives/Experls and Chairpersons of Working Groups of the Special Procedures of the Commission on Human Rights and of the Advisory Services Programme. Aprovado em Doc. E/CN.4/2000/5. 6 August 1999. Effective Human Rights Mechanisms. 
particular pode ser suficiente para cessar os abusos cometidos. Paulo Sérgio Pinheiro chama a atenção para a tensão inarredável existente entre o fact finding (investigação dos fatos) imparcial, limitação do power of embarass (poder de embaraçar) e avaliações públicas e claras, lembrando que a investigação imparcial dos fatos não-significa neutralidade, e us relatores devem denunciar abusos ou fatos para os quais há suficiente evidência. $^{104}$

Os peritos estão habilitados a realizar visitas apenas em missões oficiais, com a aprovação das autoridades pertinentes de cada país. ${ }^{105}$ No caso dos procedimentos especiais relativos aos mandatos temáticos, há a possibilidade de se fazer um convite aberto para receber visitas, o que torna a autorização para a entrada da missão desnecessária. ${ }^{106}$ Durante as visitas, os peritos interagem com atores governamentais e não governamentais. Eles exigem liberdade de pesquisa, incluindo acesso a instituições, tais como centros de detenção e prisões, e contatos com representantes e organizações não governamentais. Como procedimento padrão, o perito exige que o governo assegure que nenhuma pessoa, oficial ou privada, que tenha estado em contato com ele seja sujeita a ameaças, perseguições. punições ou processos judiciais. Algumas visitas planejadas foram efetivamente canceladas quando os governos não concordaram a conceder livre acesso a determinados lugares aos peritos ou a respeitar a natureza independente do seu trabalho. Nesse quesito, deve-se destacar que a cobertura da mídia das visitas ao país freqüentemente coloca a questão de direitos humanos no centro dos debates públicos. Os peritos com mandatos referentes a paises devem, em geral, formalizar visitas ao país em questão. Quando o acesso lhes é negado, eles viajam a outros países, particularmente os países vizinhos ao país em questão, para entrevistar refugiados e outros atores relevantes. ${ }^{107}$ Os pedidos por visitas podem ser iniciados pelos peritos ou pela $\mathrm{CDH}$ por

104 PINHEIRO, Paulo Sérgio. Monitorando para a ONL T. Politica Externa, v. 13, n. 2, 2004, p. 28.

105 Sobre termos de referência de visitas a paises, ver doc: E/CN.4/1998/45, Report of the meeting of Special Rapporteurs, Geneva. 20-23 May 1997.

106 Relação de paises que estunderam um convite aberto aos procedimentos especiais temáticos da C.DH das Naçöes Lnidas (5I paises: data base 14 de outubro de 2004): África do Sul, Alemanha, Argentina, Áustria, Bélgica, Brasil, Bulgária, Canadá, Chipre, Colômbia, Cosła Rica, Croácia, Dinamarca, Liquador, Lislováquia, Eslovênia. Espanha, Estônia, Finlândia, França, Geórgia, Grécia, Guatemala, Holanda, Hungria, Irlanda, Islândia, Itália, Letônia. Liechtenstein, Lituânia, Luxemburgo, Malta, México, Mongólia, Noruega, nova Zelândia, Paraguai, Peru, Polônia, Portugal, Reino Unido da Grã-Bretanha e Irlanda do Norte. República Islàmica do Irã. República da Macedônia. República Tcheca. Romênia, San Marino, Serra Leão, Suécia, Suiça, Turquia.

O orçamento das Naçōes Unidas permile visitas a um pais uma ou duas vezes por ano; todavia, arranjos extra-orçamentários são feitos para permitir visitas mais freqüentes. Perilos com mandatos temáticos podem decidir realizar visitas a paises considerados relevantes a seus mandatos com base em informações recebidas, assim como dependendo do tema são estimulados a visitar países representantes de todas as 
meio di resoluções específicas. A CDH pode solicitar que os peritos realizem visitas conjuntas quando us problemas de direitos humanos sejam multidimensionais, como ocorru no contexto do Timor Leste e da antiga lugoslávia. Algumas vezes, os próprios peritos podem considerar adequado realizar missões conjuntas, sendo essa uma forma de coordenação bem vinda na estrutura de direitos humanos das Nações Unidas.

Os peritos podem também desempenhar trabalho normativo e desenvolver normas mandatórias ou standards para seu trabalho. O representante do secretário-geral Relativo a Pessoas Deslocadas Internamente trabalhou com uma equipe de peritos juridicos internacionais para preparar uma compilação e uma análise das normas jurídicas pertinentes ao deslocamento interno, com base em que ele desenvolveu em 1998 os Princípios Orientadores para a Proteção dos Deslocados Internamente. Esses princípios são delineados para oferecer orientação relativa ao tratamento da questão do deslocamento interno ao Representante, aos Estados, a todas outras autoridades, a grupos, pessoas. organizações intergovernamentais e não-governamentais. O Grupo de Trabalho relativo a Detenção Arbitrária também desenvolveu um regime de ação. Na sua Deliberação n. 5, adotada em dezembro de 1990, o grupo estabeleceu, em coordenação com o Escritório do Alto Comissariado das Nações Unidas para Refugiados, critérios para regular casos de detenção arbitrária de pessoas que procuram asilo. Os peritos mantêm diálogos com os governos acerca de suas conclusões e recomendações; diálogo esse que se torna mais significativo quando o governo demonstra vontade de abordar seriamente as preocupações levantadas pelo perito (folluw-up). Durante a visita de setembro de 1999 do Relator Especial para Tortura ao Quênia, o Governo queniano designou um funcionário de alto escalão para ser o contato com o relator. O funcionário acompanhou o relator durante a missão e, em várias ocasiões, ordenou ações corretivas imediatas para corrigir a violação, como atenção médica para curtos detuntos ou a soltura de um indivíduo detido arbitrariamente. $\mathrm{O}$ Relator :special registrou em seus apontamentos públicos as medidas de resposta do Governo queniano. Em outro caso, o Relator Especial para Intolerância Religiosa desenvolveu uma matriz contendo as recomendações formuladas em seu relatório, e rotineiramente as transmite aos governos, solicitando-lhes que forneçam seus comentários e indiquem as medidas que tomaram ou pretendem tomar para implementálas, mesmo que progressivamente. Posteriormente, seguindo seu exemplo, outros peritos começaram a usar técnicas semelhantes. As respostas que eles recebem dos países são incluídas em seus relatórios, uma vez que a efetividade do sistema reside no follow up adequado das conclusões e recomendações do perito.

regiōes do mundo para captar uma perspectiva o mais ampla possivel. Nesse caso, o orçamento das Nações Unidas normalmente permite duas visitas a paist's para cada perito por ano. 
Os peritus nãu abordam somente os Estados. uma ve\% que vários mandatos solicitam que seus titulares lidem com entidades não estatais. Fntre 1996 e 2000, a perita independente para a Siluação dos Direitos Humanos na Somália relatou violaçōes cometidas por lideres de milícias naquel país, como também abordou as ações empreendidas pelas agîncias das Nações Unidas atuantes em campo na ausência de um governo central naquele país. Nessa ocasião, a perita devotou a maior parte de seu relatório em 1998 a alegações de violações cometidas pelas tropas inturnacionais na Somália. Um número crescente de mandatos passou a englobar instituições internacionais. particularmente os relativos a desenvolvimento. ajuste estrutural e divida externa, que visam considerar o impacto nos direitos humanos das políticas das instituições financeiras, como o Banco Mundial, o Fundo Monetário Internacional e a Organização Mundial do Comércio. A importância dessa consideração reside na abertura da possibilidade de debate sobre tais questões e da interação das normas internacionais de cada campo com o Direito Internacional dos Direitos Humanos, ressaltando a primazia das obrigações derivadas das normas de dircitos humanos. Algumas organizações não-governamentais de atuação em âmbito nacional, regional e internacional fornecem suporte de grande relevância ao sistema de procedimentos especiais. As organizações não-governamentais inspiraram a demanda para a criação de vários mandatos cspecíficos, e também fornecem análises e informações essenciais acerca da situação de dircitos humanos em muitos países c a respeito de muitas questões temáticas. Tal informação é verificada pelos peritos e freqüentemente transmitida aos governos para sua consideração. Além disso. as organizações não-governamentais disseminam o trabalho dos peritus a suas entidades locais. O estabelecimento de um mandato a respeito de defensores de direitos humanos em 2000 constitui um reconhecimento da contribuição indispensável dessas organizações e da necessidade de proteção de defensores, que com freqüência são perseguidos e intimidados por realizar suas tarefas relativas a direitos humanos.

Dıvido aos recursos limitados do Secretariado, os peritos cm geral recorrem a seus próprios recursos para apoiar suas pesquisas e dependem do apoio que recebem do ACDH. ${ }^{108}$ Paulo Sérgio Pinheiro aponta que os peritos de direitos humanos recebum

108 Não-obstante os recursos escassos que prejudicam o atingimento do pleno potencial, são contínuos os esforços para fortalecer o sistema no intuito de atingir a muta de respeito universal por todos os direitos humanos. Nessa tarefa, a cooperaçào de variados atores. en particular os governos. os demais órgãos, agências c programas das Nações Unidas e o sctor não governamental, pode contribuir de forma considerável para maior efetividade desse sistema. Os procedimentos especiais devem buscar a coordenação e o diálogo com outros atores, particularmente do sistema das Naçōes Unidas. Nas resoluçōes que estabelecem os mandatos, o Secretário-geral é em geral solicitado a apoiar o trabalho dos peritos. o que e visto principalınente cumo um apoio politico e financeiro do orçamento regular das Naçóes I nidas: e sempre é mencionada a assistência provida pelo F.scritório do $A C D H$ e das variadas agências especializadas 
apenas reembolso pelas despesas relacionadas a viagens, e que a lógica desse serviço pro bono seria assegurar que os peritos de direitos humanos tenham mais autonomia do que um funcionário das Nações Unidas. ${ }^{109}$ Todavia, há um código de conduta, conforme debatido pela Assembléia Geral, que deve ser aplicado a todos os peritos $\mathrm{cm}$ missão, incluindo os peritos de direitos humanos. ${ }^{110} \mathrm{O}$ aumento no número de mandatos, sem um correspondente aumento nos recursos para suportá-los, gera dificuldades na operacionalização dos procedimentos especiais. Os peritos também exercem um grau de auto-regulação. quando se reúnem anualmente para deliberar acerca de questões relativas a seus mandatos. Durante essas reuniões, eles consideram problemas de interesse comum, tais como seus métodos de trabalho. Eles também têm discussões com o $\mathrm{ACDH}, \mathrm{o}$ escritório da $\mathrm{CDH}$, os presidentes dos mecanismos convencionais de direitos humanos das Nações Unidas estabelecidos pelos principais tratados de direitos humanos das Nações Unidas e com organizações não-governamentais.

\section{Resultados dos procedimentos especiais para direitos humanos}

Como visto. em seus relatórios submetidos à $\mathrm{CDH},{ }^{\prime \prime \prime}$ os peritos ressaltam situações que merecem atenção internacional, oferecendo, em geral, uma análise de grande importância da situação dos direitos humanos em um país específico ou de um determinado tema. A título de exemplificação, o antigo relator especial para Exccuções Sumárias, Arbitrárias e Extrajudiciais inseriu a questão do assassinato de mulheres em

da organização. Por exemplo, em 4 de março de 1998, o ACDH concluiu um Memorando de Entendimento com o PNUD, segundo o qual o PNUD e o ACDH deveriam cooperar de forma a implementar aspectos dos mandatos dos grupos de trabalho e procedimentos especiais temáticos e de paises. A cooperação entre o PNUD e o ACDFl visa fortalecer a efetividade e a eficiência das missões de investigação dos fatos de direitos humanos. Os escritórios locais do PNID estenderam seu apoio logístico e substantivo antes e durante as missōes. O PNUD tamtém disponibilizou importantes relatórios e documentos de avaliação a respeito dos paises a serem examinados.

109 Paulo Sérgio ressalta que nas reuniōes anuais dos procedimentos especiais, ele tem argumentado que os peritos de direitos humanos deveriam ser remunerados, como qualquer outro perito das Nações Unidas $\mathrm{cm}$ uma missão oficial. Segundo ele, o registro histórico não demonstra vinculo necessário entre remuneração e retidão politica. A principal vantagem a ser ganha da remuneração do trabalho dos relatores especiais seria alterar a imagem de indicados como uma elite acadêmica, politica e diplomática, capaz de se bancar. A possibilidade de oferecer remuneração para o trabalho dos relatores especiais seria tomar as indicaçòes abertas a uma gama mais ampla de peritos e ativistas das organizações da sociedade civil. PINHEIRO, Paulo Sergio. Musings of a UN Special Rapporteur on Human Rights. Global Governance. n. 9, 2003, p. 9.

110 Doc. NU: A/54/695. Proposed Regulations Governing the Stutus. Basic Rights and Duties of Officials other than Secretariat Officials and Experts on Mission.

$111 \mathrm{O}$ trabalho dos peritos é debatido em sessões anuais da $\mathrm{CDH}$ : mas eles também podem relatar à Assembléia Geral e menos freqüentemente ao Conselho de Segurança, mediante a fórmula Arria, segundo a qual esse órgão pode escutar interlocutores outros que não representantes dos Estados ou funcionários de alto escalão das Nações Unidas. Doc. NU: E/CN.4/2002/14, 11 seplumber 2001, Effective functioning of the human rights mechanism. 
nome da honra na agenda internacional. Em novembro de 2000, a Assembléia Geral das Nações Unidas adotou sua primeira resolução em que condenou esse crime, que por décadas tem sido praticado com impunidade contra milhares de mulheres em muitas partes do mundo. ${ }^{12}$ Muitos relatórios nomeiam vítimas e descrevem as alegações das violações de seus direitos humanos, e os peritos algumas vezes intervêm em nome das vítimas. Além disso, os relatórios dos pcritos freqüentemente servem como um importantc aviso inicial de um possivel agravamento da situação e da necessidade de medidas urgentes, ponto em que o relato dos abusos assume um papel ativo na prevenção da deterioração da situação dos direitos humanos. Por exemplo, antes da ocorrência do genocídio em Ruanda, em abril de 1993, o então relator especial para Execuções Sumárias, Arbitrárias e Extrajudiciais, Sr. Bacre Nduaye, visitou esse país e relatou acerca da grave violência étnica que ocorria. A comunidade internacional, notadamente a missão das Nações Unidas em Ruanda, não observou ou forneceu uma resposta adequada a esse significante aviso. o que poderia ter evitado ou pelo menos reduzido as proporções do ocorrido. $^{113}$ Não-obstante essa demonstração frustrada, há resultados concretos decorrentes dos trabalhos desempenhados pelos peritos. Durante suas visitas a países, alguns peritos conseguem obter alivio para vitimas, como foi o caso, em janeiro de 1992 , quando o Relator Especial para a Situação dos Direitos Humanos no Afeganistão conseguiu obter uma decisão presidencial do então presidente Najibullah para comutar as penas de morte de quase 114 pessoas para termos de prisão de 20 anos.

Embora seja grande o potencial do trabalho dos peritos para fomentar mudanças, é difícil atribuir resultados concretos no campo dos direitos humanos a um só fator. Muito depende de como os governos, a sociedade civil em um país particular e a comunidade internacional reagem às verificações das violações, conclusões e recomendações dos peritos. O exame contínuo de uma situação particular, entretanto, assinala à vítima que sua triste situação não foi esquecida pela comunidade internacional e concede-Ihe a oportunidade de dar voz a suas demandas. Por outro lado, aqueles que promovem as violações dos direitos humanos sabem que, de alguma forma, não mais estão atuando à margem dos olhares do mundo, e as autoridades envolvidas sabem que a avaliação de seus registros de direitos humanos terão um impacto nas considerações políticas, desenvolvimentistas e humanitárias, o que exige maior responsabilidade e

11. Mulheres são assassinadas por seu pai ou irmãos por atos considerados como manchas a honra da familia, incluindo o adultério, não acatamento de uma ordem parental para se casar, ser vista em público com um homem ou se tornar vitima de um estupro, um crime que muitas pessoas ainda acreditam que não poderia acontecer sem o consentimento da vilima.

113 Doc. NU: E/CN.4/2002/14, 11 septernber 2001, Effective Functioning of Human Rights Mechanisms, $\$ 35$. 
resulta em mudanças de melhoria na situação examinada. Além disso, a publicidade desses relatórios permite que os indivíduos tomem uma posição frente às violações, exercendo sua participação no contexto politico em âmbito nacional e influenciando o desenvolvimento das relações internacionais em conseqüència dos princípios democráticos.

Sabe-se que a privação de direitos humanos encontra-se na raiz ou no resultado de tunsões que conduziram a muitos conflitos em difurentes partes do mundo. A maior ocorrência de conflitos de natureza não internacional nos últimos anos, ou mesmo de conflitos internacionais promovidos em nome da guerra contra o terrorismo, contribui para evidenciar a relação entre paz e segurança, assuntos econômicos, sociais e culturais, demucratização, desenvolvimento e questões humanitárias. Os procedimentos especiais de direitos humanos das Nações Unidas podem ser considerados como uma alternativa capaz de contribuir para a disseminação de informações absorvidas em uma perspectiva mais ampla para basear as decisões da sociedade internacional e para proporcionar uma maior participação consciente dos cidadãos de todas as partes do mundo na construção de uma verdadeira democracia. Os peritos dos procedimentos especiais de dircitos humanos das Nações Unidas desempenham um papel essencial no trabalho rumo à realização universal clos direitos humanos, contribuindo para o afastamento do medo e da necessidade no seio da comunidade internacional.

\section{Conclusão}

Os procedimentos especiais de direitos humanos das Nações Unidas têm contribuído para tornar o debate intergovernamental acerca de direitos humanos mais próximo da realidade. Fsses procedimentos trouxeram à luz questões graves, tais como os desaparecimentos forçados, a brutalidade policial. as execuções sumárias, o assassinato de mulheres em nome da honra, o sofrimento das crianças de rua, a perseguição de minorias étnicas em muitas sociedades, o papel dos atores não-estatais nas violações de direitos humanos, o vínculo entre a pobreza extrema e o respeito aos direitos humanos e o impacto de outras violações de direitos humanos. Ao papel de formador de um arcabouço informacional confiável e yue proporciona maior compreensão das diferenças locais soma-se a sua contribuição para o fortalecimento das capacidades institucionais nacionais de forma a encerrar as perpetrações de violações e eliminar os obstáculos à realização dos direitos humanos. e para a potencialização da participação consciente dos indivíduos, em decorrência dos princípios democráticos, no processo decisório orientador das politicas internacionais de cada Estado. 
Os métodos de trabalho dos peritos são flexíveis e permitem uma adaptação a situações específicas, sem que se constitua uma intervenção à soberania do Estado. Conforme referência feita por Hannah Arendt às palavras de Mommsen, a autoridade é mais que um conselho e menos que uma ordem; um constho que não sc' pode ignorar sem risco. ${ }^{114}$ A perspectiva que busca a averiguação de dados factuais, basuada na análisı in loco de uma situação de violações em um país. no caso dos mandatos de países, ou de um tema específico, no caso dos mandatos temáticos, proporciona um melhor conhecimento e maior compreensão do mundo, e das possibilidades de ações adequadas, dotadas de coerência e consistência. As palavras dos relatores, peritos e representantes não são acompanhadas por uma sanção, mas pelo risco de sua desconsideração em relação à dignidade do ser humano. Para que essa autoridade possa ser preservada, os procedimentos especiais devem atuar no interesse da verdade. da justiça, e independentemente da pressão de governos ou entidades públicas e privadas; e os peritos devem também se distanciar de scus próprios preconceitos, para descrever uma deturminada situação e aconselhar acerca das medidas a sırem tomadas.

Como observou a presidente da CDH. Sra. Najat Al-Hajjaji, " na reunião anual dos peritos de 2003, os procedimentos especiais são os olhos e os ouvidos da CDH: eles representam a consciência da humanidade. Há, pois, necessidade de garantir sua liberdade para que scja preservada sua capacidade de relatar e avaliar, sem coerções de qualquer tipo. Nesse contexto, enquanto estiverem no desempenho de missões, os titulares de mandatos de procedimentos especiais devem gozar de imunidades e privilégios que garantam os interesses da sociedade internacional, representada pelas Nações Unidas. Nesse particular. há diferenças entre a imunidade de funcionários de Estado, dos funcionários ou de outros agentəs das Nações Unidas, quando atuam nos interesses da comunidade internacional representada pelas Nações Unidas, e não em nome de qualquer Fstado particular. A jurisprudência a respeito da determinação pelos tribunais domésticos de questões relativas às imunidades dos representantes ou funcionários oficiais de um Estado para suas ações em outro Estado não é assim necessariamente aplicável em sua inteireza no caso dos peritos de direitos humanos como peritos em missão. Seu stalus jurídico consta na seção 22 do art. VI da Convenção das Nações Unidas relativa a

\footnotetext{
114 ARENDT, Hannah. O yue é autoridade. In: ARENDT. Hannah. Lintre o passado e o futuro, p. 165.

115 Doc. NU: E/CN.4/2004/4. 5 August 2003, Effective functioning of human rights mechanisms, $\$ 44$.
} 
Privilégios e Imunidades, de 1946, e deve ser respeitado para que a essência dos procedimentos especiais seja preservada.

São Paulo, dezembro de 2005.

\section{Referências}

ARAGÃ(). Eugênio José Guilherme de. ONU e o Judiciário. Observatório da Imprensa, Matérias, 11/I1/2003.

ARENDT, Hannah. Fntre o passado e o futuro. Tradução de Mauro W. Barbosa. São Paulo: Editora Purspectiva, 2001.

ARENDT. Hannah. Crises da república. Tradução Josí Volkmann, São Paulo: Perspectiva, 1973.

LAFER, Celso. A mentira: um capítulo das relações entre a ética e a politica. In: NOVAES. Adauto (Org.). Ética. São Paulo: Companhia das I.etras; Secretaria Municipal de Cultural, 1992. p. 225-237.

MAGALHÃES, José Carlos de. A prisão do depositário infiel: um ilícito internacional. Revista dos Tribunais. Ano 89. v. 771, p. 77-86; 98-99, jan. 2000.

PINHEIRO, Paulo Sérgio. Monitorando para a ONU. Politica Externa, v. 13, n. 2, p. 21-32, 2004.

PINIIEJRO, Paulo Sérgio. Musings of a UN Special Rapporteur on lluman Rights. Global Governance, n. 9, p. 7-13. 2003.

PINHEIRO. Paulo Sérgio: GAMA. Marcos Pinta. Portas abertas às Nações Unidas. Jornal 'O Globo'. 15 de abril de 2002.

SOARES. Guido Fernando Silva. Imunidade de jurisdição e foro por prerrogativa de função. Texto baseado nas notas taquigráficas de conferência proferida no Seminário Internacional $O$ Tribunal Penal Internacional e a Constituição Brasileira, promovido pelo Centro de Estudos Judiciários do Conselho da Justiça Federal, em 30 de setembro de 1999, no auditório do Superior Tribunal de Justiça, em Brasília-DF.

SOARES, Guido Fernando Silva. Origens e Justificativas da Imunidade de Jurisdição. Parte substancial desse trabalho foi retirada de uma comunicação escrita apresentada pelo autor: Evolução c Perspectivas do Conceito de Imunidades de Jurisdição, por ocasião das Jornadas de Direito Internacional, organizadas pelo Ministério das Relações Exteriores, através do Instituto Rio Branco. pela Advocacia Geral da União e pela Secional de Brasilia da Ordem dos Advogados do Brasil. no auditório do referido Instituto Rio Branco, em Brasília, de 25 a 26 de fevereiro de 2000. 
TRINDADF:, Antônio Augusto Cançado. Direito das Organizações Internacionais. 2. ed. Belo Horizonte: Del Rey, 2002. p. 23.

Documentos da Corte Internacional de Justiça:

Doc. CIJ: Difference Relating to Immunity from Lcgal Process of a Special Rapporteur of the Cornmission on Human Rights, Summary of the Advisory Opinion of 29 April 1999.

Doc. CIJ: Applicability of article VI, section 22, of the Convention on the Privileges and Immunities of the United Nations, Advisory Opinion of 15 December 1989.

Documentos das Nações Unidas (United Nations High Commissioner for Human Rights):

Doc. NU: Seventeen frequently asked questions about the United Nations Special Rappourteurs. Human Rights Fact Sheet 27.

Doc. NU: Communications Procedures. Human Rights Fact Sheet 7.

Doc. NU: Complaint procedures. Human Rights Fact Sheet n. 7/Rev.I.

Doc. NU: A/54/695. Proposed Regulations Governing the Status, Basic Rights and Duties of Officials other than Secretariat Officials and Experts on Mission.

Doc. NU: E/CN.4/2004/4. 5 August 2003, Effective functioning of human rights mechanisms.

Doc. NU: E/CN.4/2002/14, I1 September 2001, Effective Functioning of Human Rights Mechanisms.

Doc. UN: E/CN.4/2000/112, Report of the Inter-sessional Working Group on Enhancing the Fffectiveness of the Mechanisms of the Commission on Human Rights.

Doc. NU: E/1998/94, 28 July 1998, Privileges and limmunities of the Special Rapporteur of the Commission on Human Rights on the Independence of Judges and Lawyers.

Documentos relativos a reuniões dos relatores especiais, representantes, peritos e presidentes de grupos de trabalho dos procedimentos especiais da Comissão de Direitos Humanos:

Doc. NU: E/CN.4/1995/5, Report on the meeting of special rapporteurs/representatives/experts and chairpersons of working groups.

Doc. NU: E/CN.4/1996/50, Note by the High commissionur for Human Rights transmitting the report of the special rapporteurs/representatives/experts and chairpersons of working groups of the special procedures of the Commission on Human Rights and of the advisory scrvices programmes. 
Doc. NU: E/CN.4/1996/50/Add.1, Note by the High Commissioner for Human Rights contains the texts of the address of the High Commissioner for Human Rights and that of the Assistant Secretary-General for Human Rights at the meeting of special rapporteurs/representatives/experts and chairpersons of working groups of the special procedures of the Commission on Human Rights and of the advisory scrvicus programme.

Doc. NU: E/CN.4/1997/3. Report of the meeting of Special Rapporteurs/Representatives Experts and Chairpersons of Working Groups of the Special, Procedures and of the Advisory Services Programme.

Doc. NU: E/CN.4/1998/45, Report of the meeting of Spccial Rapporteurs, Geneva, 20-23 May 1997.

Doc. NU: E/CN.4/1999/3 and Corr.l. Report of the meeting of Special Rapporteurs, Geneva, 26 to 29 May 1998.

Doc. NU: E/CN.4/1999/3/Add. I and Corr.2, Study of the High Commissioner for Human Rights on procedures for ensuring implementation of, and follow-up to recommendations of special rapporteurs/representatives, experts and working groups

Doc. NU: E/CN.4/1999/3/Add.2. Report of the Chairperson of the fourth meeting of special rapporteurs/representatives, experts and chairpersons of working groups of the Commission on Human Rights and of the advisory services programme concerning his activities from June 1997 to May 1998.

Doc. NU: E/CN.4/2000/5. Report of the meeting of special rapporteurs. representatives, experts and chairpersons.

Doc. NU: E/CN.4/2001/143, Rationalization of the work of the Commission.

Doc. NU: E/CN.4/2002/14, Effective functioning of Human Rights Mechanisms.

Doc. NU: E/CN.4/2004/4, Effective functioning of Human Rights Michanisms. 